\title{
THE PHYLLOTAXY OF COSTUS (COSTACEAE)
}

\author{
BRUCE K. KIRCHOFF AND ROLF RUTISHAUSER
}

\begin{abstract}
Department of Biology, University of North Carolina, Greensboro, North Carolina 27412-5001; and Botanischer Garten, University Zürich, Zollikerstrasse 107, CH-8008 Zürich, Switzerland The spiromonostichous phyllotaxy of Costus, and other Costaceae, is characterized by low divergence angles, often as low as $\left(30^{\circ}-\right) 50^{\circ}$. This constrasts with the main series Fibonacci (divergence angles approximating $137.5^{\circ}$ ) or distichous phyllotaxy found in all other Zingiberales. A morphological and developmental study of three species of Costus revealed a number of facts about this unusual phyllotactic pattern. In $C$. scaber and $C$. woodsonii the divergence angles gradually change along a shoot, from $140^{\circ}-100^{\circ}$ in the region of the cataphylls to $60^{\circ}-45^{\circ}$ in the inflorescence. In C. cuspidatus, the divergence angles change from $40^{\circ}-100^{\circ}$ in the cataphyll region to ca. $137^{\circ}$ in the inflorescence. In all three species, the cataphylls and foliage leaves have tubular sheaths, while the inflorescence bracts are nonsheathing. Thus, spiromonostichy is only loosely correlated with closed leaf sheaths.
\end{abstract}

Kirchoff, B. K. and R. Rutishauser. 1990. The phyllotaxy of Costus (Costaceae). Botanical Gazette 151: $\underline{88-105}$.

Made available courtesy of University of Chicago Press: http://www.journals.uchicago.edu/doi/abs/10.1086/337808

\section{Introduction}

HOFMEISTER (1868) noted that, in normal phyllotactic systems, leaf primordia at the apex appear as far as possible from each other. This generalization is known as Hofmeister's rule (WEISSE 1932; SMITH 1941; JEAN 1984) and is the basis of many of the theories that attempt to explain phyllotactic patterns. In most flowering plants with helical phyllotaxy, the divergence angle between consecutive leaves lies between $120^{\circ}$ and $180^{\circ}$. Most common are the Fibonacci systems of the main series, with divergence angles around $137.5^{\circ}$.

The phyllotactic patterns in the Costaceae (figs. 1-54) are unusual for at least two reasons. First, the divergence angles on aerial shoots can be as low as $30^{\circ}$ (fig. 5, Dimerocostus strobilaceus $\mathbf{0 .}$ Kuntze), seemingly in violation of Hofmeister's rule (SMITH 1941). These small divergence angles are occasionally correlated with helical twining of the stem to give the shoot the appearance of a spiral staircase (fig. 4). Second, there is a gradual change of the divergence angles along the aerial shoots from ca. $120^{\circ}$ to $\left(30^{\circ}-\right) 40^{\circ}-60^{\circ}$ (WEISSE 1932 ).

Many botanists have been attracted and puzzled by this unusual phyllotactic pattern: HOFMEISTER (1868, p. 499), SCHUMANN (1892, 1904), LINDMAN (1899), GOEBEL (1928, p. 293), SCHUEPP (1928), VON VEH (1931), WEISSE (1932), TROLL (1937), SMITH (1941), SNOW (1952), CROIZAT (1960, pp. 712-722), and JEAN (1984). Although all of these authors have contributed to our knowledge of the phyllotaxy of this family, none produced a satisfactory theory to account for the phenomena.

The purpose of the present study is (1) to confirm or to correct the observations of earlier bot-

Manuscript received June 1989; revised manuscript received September 1989.

Address for correspondence and reprints: BRUCE K. KIRCHOFF, Department of Biology, University of North Carolina, Greensboro, North Carolina 27412-5001. anists, (2) to present new data on the gradual change in divergence angles along aerial shoots, (3) to investigate developmental and anatomical features correlated with the gradual change in divergence angle in Costus, and (4) to review theories that attempt to explain the phyllotactic pattern in the Costaceae.

\section{Material and methods}

Phyllotactic patterns were studied in Costus scaber Ruiz et Pavon, C. woodsonii Maas, and $C$. cuspidatus (Nees \& Martius) Maas (syn. C. igneus N. E. Brown). Additional information was obtained from C. afer Ker.-Gawl. and Dimerocostus strobilaceus 0. Kuntze. The species were identified by consulting MAAS'S $(1972,1977)$ monograph of Costus for Flora Neotropica. Costus scaber was collected at Fairchild Tropical Garden, Miami, during the summers of 1984-86 and in December 1987 (FTG accession number P.609). A voucher specimen is deposited at FTG (KIRCHOFF 84-6). Costus woodsonii was collected at Fairchild Tropical Garden in 1984. A voucher is deposited at FTG (KIRCHOFF 84-29). Costus cuspidatus was collected at the Botanical Garden, Zurich. A voucher is deposited at Z (RUTISHAUSER 88-1001). Costus afer was observed at Fairchild Tropical Garden and Dimerocostus strobilaceus was observed at Waimea Arboretum, Hawaii.

Divergence angles were measured for nine shoots of C. scaber, three of C. woodsonii, and three of C. cuspidatus. Measurements were made by inserting a pin perpendicularly through the axillary buds of two adjacent nodes and using a protractor to measure the angle between the pins at the point of their insertion into the stem. Some of the variation in divergence angles in the foliage regions of the study species (figs. 20-22) can most likely be attributed to this measurement technique. Calculations of the divergence angle in the middle and upper portions of the inflorescence of $C$. scaber ${ }_{88}$ (fig. 20b) were made from a drawing prepared with 

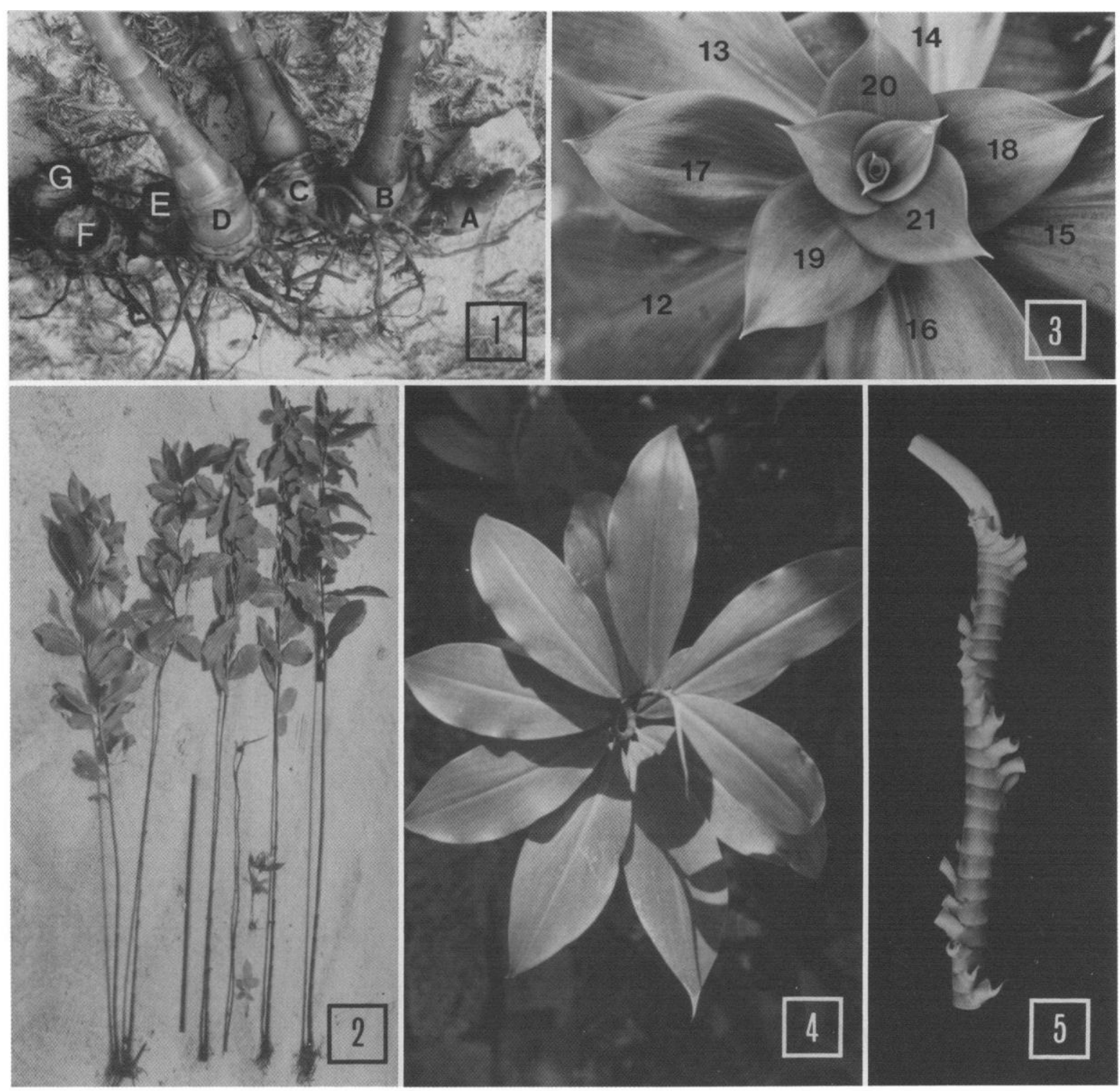

Figs. 1-5.-Figs. 1-2, Costus scaber. Fig. 1, Distal portion of a sympodial rhizome. $A=$ new aerial shoot; $B-D=$ mature aerial shoots; $E-G=$ scars of abscised shoots. $\times 0.17$. Fig. 2, Aerial shoots ranging in length from 2 to $2.8 \mathrm{~m}$, stick $=1 \mathrm{~m}$. $\times$ 0.04. Fig. 3, Costus cuspidatus. Young inflorescence seen from above. The flowers are not yet visible in the axils of the bracts. Bracts arranged in a Fibonacci spiral, with divergence angles around $137^{\circ}$. Phyllome $14=$ lowermost bract subtending a flower. $\times 0.32$. Fig. 4, Costus afer. Helical curvature of an aerial shoot. The divergence angle between successive leaves in ca. $45^{\circ} . \times$ 0.17 . Fig. 5 , Dimerocostus strobilaceus. Distal portion of an aerial shoot with leaf blades removed. The divergence angle is ca. $30^{\circ} . \times 0.2$.

special attention to the accurate representation of the divergence angles (fig. 10). Two bracts along the same orthostichy were first identified in the drawing; the number of degrees between these bracts was then determined and divided by the difference between the numbers of the two bracts. For example, bracts 56 and 67 in figure 10 were found to be superposed after two turns of the phyllotactic spiral; the divergence angle in this region is thus $720^{\circ} / 11=65.5^{\circ}$. To get the best estimate of the divergence angles in the upper portion of the in- florescence, this process was repeated as many times as possible, given the number of bracts in the drawing. Measurements of divergence angles at the apex were made from scanning electron micrographs. Lines were drawn from the shoot apex through the middle of the primordium (fig. 29) or through the buds in the axils of removed phyllomes (fig. 32). The angle between phyllomes was measured with a protractor.

Mean blade lengths and their standard deviations were calculated for the mature foliage leaves for 


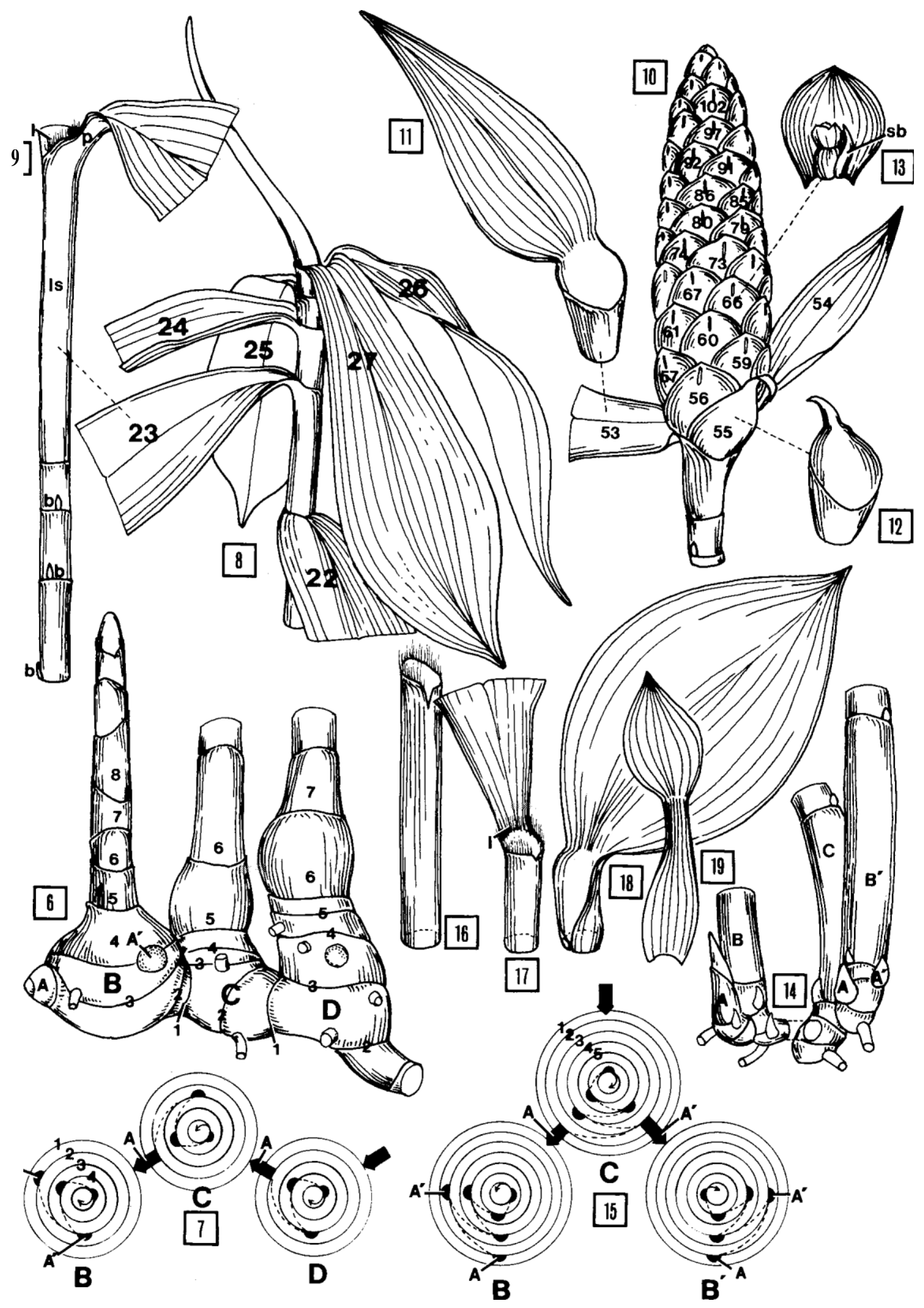



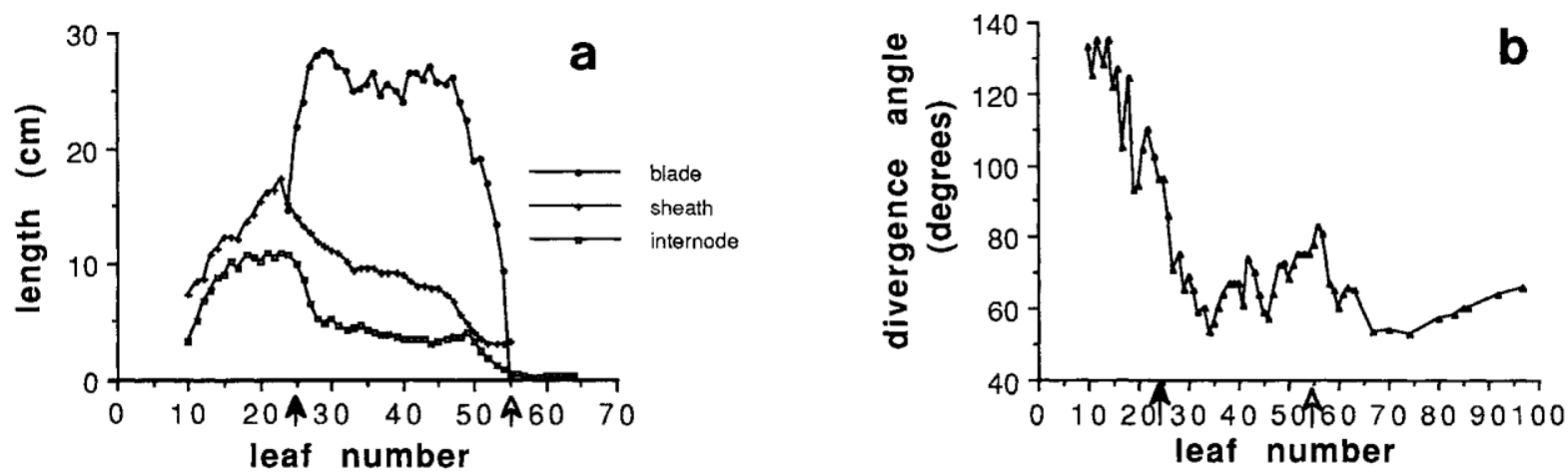

Fig. 20.-Costus scaber. $a$, Change of internode, sheath, and blade lengths along a single shoot. $b$, Divergence angles. Solid arrow $=$ lowermost foliage leaf; open arrow $=$ uppermost foliage leaf.
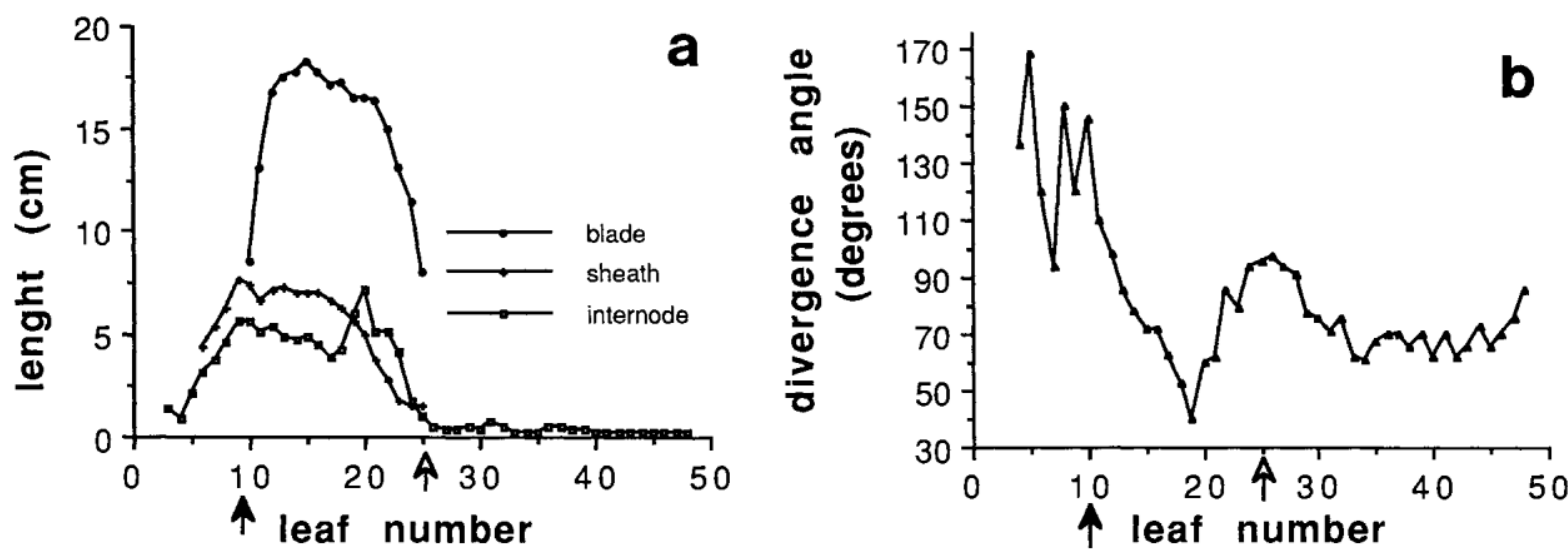

Fig. 21.-Costus woodsonii. a, Change of internode, sheath, and blade lengths along a single shoot. $b$, Divergence angles. Solid arrow $=$ lowermost foliage leaf; open arrow $=$ uppermost foliage leaf.

Figs. 6-19.-Figs. 6-13, Costus scaber. Fig. 6, Distal portion of a sympodial rhizome with four modules $(A-D)$. The phyllomes, or their scars, are labeled with arabic numerals along each module. The internodes are referred to by the number of their subtending leaves. $1=$ prophyll; $2-3=$ cataphylls subtending the renewal buds; $A=$ renewal bud; $A^{\prime}=$ enlarged bud that occasionally functions as a renewal bud; $B=$ young aerial shoot; $C-D=$ basal portions of aerial shoots 1.7 and $2 \mathrm{~m}$ tall, respectively. $\times 0.6$. Fig. 7 , Schematic diagram of the branching pattern of the rhizome shown in fig. 6 , as seen from above. Each circle represents the insertion of one leaf, with the prophyll marked by the outermost circle (1). Straight arrows $=$ direction of growth of new modules; curved arrows in innermost circles = direction of rise of the phyllotactic helix; dotted lines = connections between adjacent enlarged buds. $\times 0.6$. Fig. 8, Distal portion of $1.8 \mathrm{~m}$ aerial shoot. Leaf 22 is the fifth foliage leaf. Leaves 22-27 are separated by divergence angles of ca. $72^{\circ}$. The anodic margin of the leaf encloses the cathodic margin in bud. $\times 0.6$. Fig. 9, Portion of the aerial stem showing one foliage leaf and three axillary buds $(b) . l=$ ligule; $l s=$ tubular leaf sheath; $p=$ petiole $\times 0.6$. Fig. 10, Terminal inflorescence subtended by three transition leaves (53-54). The bracts are labeled according to their position on the sinistrorse ontogenetic helix. Fig. $20 b$ shows the divergence angles within this inflorescence. $\times 0.6$. Fig. 11 , Transition leaf (no. 53) with tubular sheath. $\times 0.6$. Fig. 12, Lowermost bract with tubular sheath and blade rudiment. $\times 0.6$. Fig. 13, Bract with nontubular base, subtending a single flowered cincinnus. $s b=$ secondary bract. $\times 0.6$. Figs. 14-19, Costus cuspidatus. Fig. 14, Distal portion of a sympodial rhizome with three well-developed modules $\left(B, C, B^{\prime}\right)$ and renewal buds $(A$, $\left.A^{\prime}\right) . \times 0.6$. Fig. 15 , Schematic diagram of the branching pattern of the rhizome shown in fig. 14, as seen from above. Each circle represents the insertion of one leaf, with the prophyll marked by the outermost circle (1). Straight arrows $=$ direction of growth of new modules; curved arrows in innermost circles $=$ direction of rise of the phyllotactic helix; dotted lines $=$ connections between adjacent enlarged buds. $\times 0.6$. Fig. 16, Cataphyll from the base of module $B^{\prime}$ in fig. $14 . \times 0.6$. Fig. 17, Basal portion of a $28-\mathrm{cm}$-long foliage leaf. The tubular sheath is topped by a fimbriate ligule $(l) . \times 0.6$. Fig. 18 , Leaf-like lower inflorescence bract, with partially tubular sheath. $\times 0.6$. Fig. 19, Upper inflorescence bract with nontubular sheath and relatively short blade. 

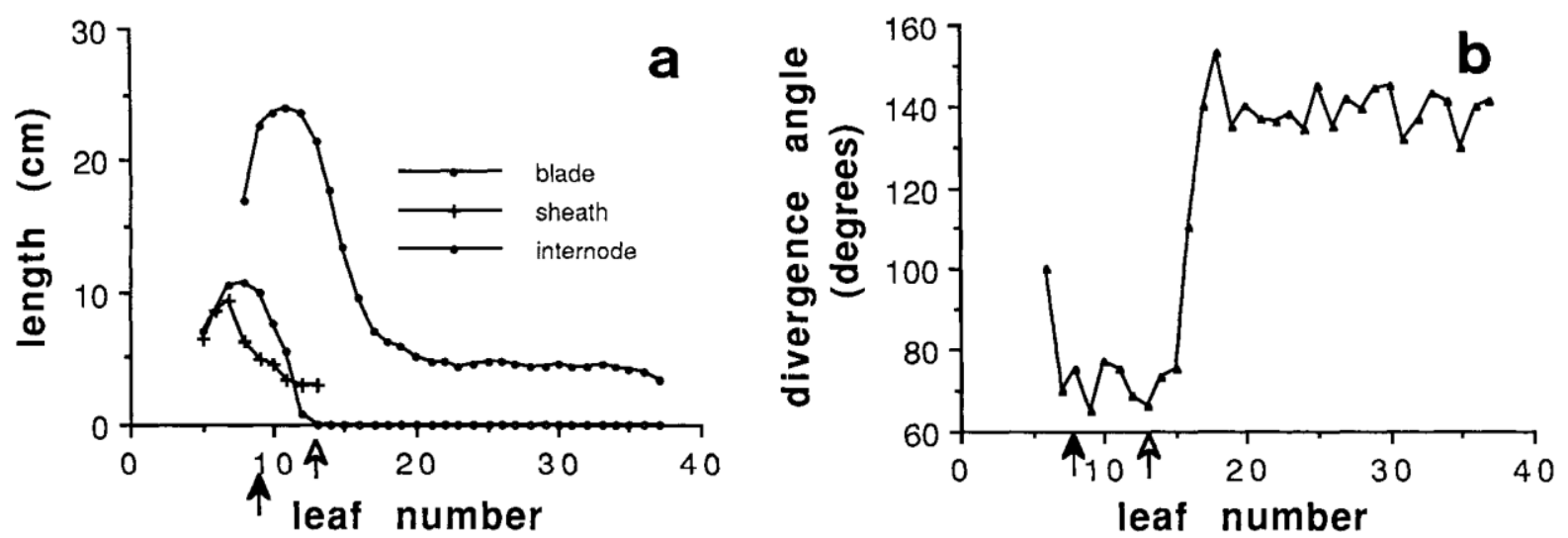

Fig. 22.-Costus cuspidatus. a, Change of internode, sheath, and blade lengths along a single shoot. $b$, Divergence angles. Solid arrow $=$ lowermost foliage leaf; open arrow $=$ uppermost foliage leaf.

one shoot of C. scaber and one of C. woodsonii. Transition leaves between the cataphylls and foliage leaves and between the foliage leaves and inflorescence bracts were excluded from these calculations. Transition leaves were identified as those leaves with a blade length distinctly shorter than the mean blade length. The borderline between foliage and transition leaves was determined from graphs of blade length versus leaf number (figs. 20a, 21a). This method was not useful for C. cuspidatus because of the gradual change from foliage leaves to bracts that occurs in the inflorescence of this species. Mean blade length is not reported for C. cuspidatus.

Vegetative and reproductive apices were fixed in formalin-acetic acid-alcohol (BERLYN and MIKSCHE 1976). For scanning electron microscopy, dissected shoot tips were critical-point dried and sputter-coated with gold/palladium. Scanning electron micrographs were taken on a Cambridge S4 scanning electron microscope operated at $15 \mathrm{kV}$. For microtome sectioning, the fixed material was embedded in Paraplast or Tissue Prep 2 and sectioned at 4-1011. The sections were stained with safranin/astrablue or safranin/fast green (BERLYN and MIKSCHE 1976). Photographs were taken on an Olympus photomicroscope.

Since $C$. scaber differs from $C$. cuspidatus in a number of respects (table l), these two species were compared developmentally. C. woodsonii resembles $C$. scaber (table 1), and thus only supplementary developmental data are presented for this species.

\section{Results}

\section{ARCHITECTURE OF THE RHIZOME}

Costus scaber. - Like many members of the Zingiberales, C. scaber is a rhizomatous plant with sympodial growth, well-developed aerial shoots, and a terminal inflorescence (figs. 1-3). The plants are constructed according to Tomlinson's architectural model (HALLE 1979). The aerial shoots may

FIGs. 23-24.-Costus scaber. Scanning electron micrographs of renewal bud, cataphyll, and foliage leaf development. Fig. 23 , Young renewal bud inserted on the internode above the subtending cataphyll (removed, $c$ ). Note totally sheathing prophyll $(p r) . \times 105$. Fig. 24, Renewal bud at a later stage of development. $p r=$ prophyll. $\times 75$. Fig. 25, Renewal bud after removal of prophyll. $2=$ second cataphyll, $a=$ shoot apex. $\times 150$. Figs. $26-28$, Scanning electron micrographs of the shoot apex and youngest cataphylls of a renewal bud. Fig. 26, Polar view. Nine cataphylls have been removed. Radii are drawn from the apex to the positions of the two renewal buds $(r 2, r 3)$. The divergence angle between the renewal buds is ca. $120^{\circ}$. $\times 15.6$. Fig. 27 , Polar view of the youngest primordia. Radii are drawn from the apex through the medial plane of the leaf primordia. The divergence angles between cataphylls $10-12$ is ca. $120^{\circ}$. Arrow = notch in sheath of phyllome $10 . \times 78$. Fig. 28 , Oblique/lateral view of the apical region. Close contact between the distinctly hooded cataphyll 10 and the apex $(a)$ is evident. Cataphylls 11,12 and 14,15 show a distinct marginal overlap. An initiating primordium may be seen between cataphylls 14 and 15 . Arrow $=$ notch in sheath of phyllome 10. $\times 72$. Figs. 29-31, Micrographs of the apical region of an aerial shoot during transition from cataphyll to foliage leaf production. Twenty cataphylls have been removed from the shoot. Phyllome 21 is most likely the first foliage leaf. Fig. 29, Polar view. Radii are drawn from the apex (a) through the center of each primordium, 21 and 22 . The divergence angle between these phyllomes is ca. $115^{\circ} . \times 155$. Figs. 30-31, Two lateral views of the same apical region shown in fig. 29. Note the tubular sheaths of leaf 21 and the open sheath of primordium 22. Both $\times 155$. Figs. 32-34, Scanning electron micrographs of the shoot apical region of a well-developed aerial shoot. Fig. 32, Polar view of the apical region. Foliage leaf primordia 4045 have been removed at their level of insertion. Radii are drawn from the center of the shoot to the positions of the axillary buds of the consecutive leaves (40-45). The axillary bud of leaf 43 is not visible and has no radius drawn through it. The divergence angle is ca. $60^{\circ} . \times 33$. Fig. 33, Polar view. Note the well-developed, asymmetric sheath on primordium 46. Arrow $=$ notch in leaf sheath; $a n=$ anodic margin of primordium; $c a=$ cathodic margin of primordium. $\times 132$. Fig. 34 , Lateral view. Arrow $=$ notch in leaf sheath. $\times 140$. 


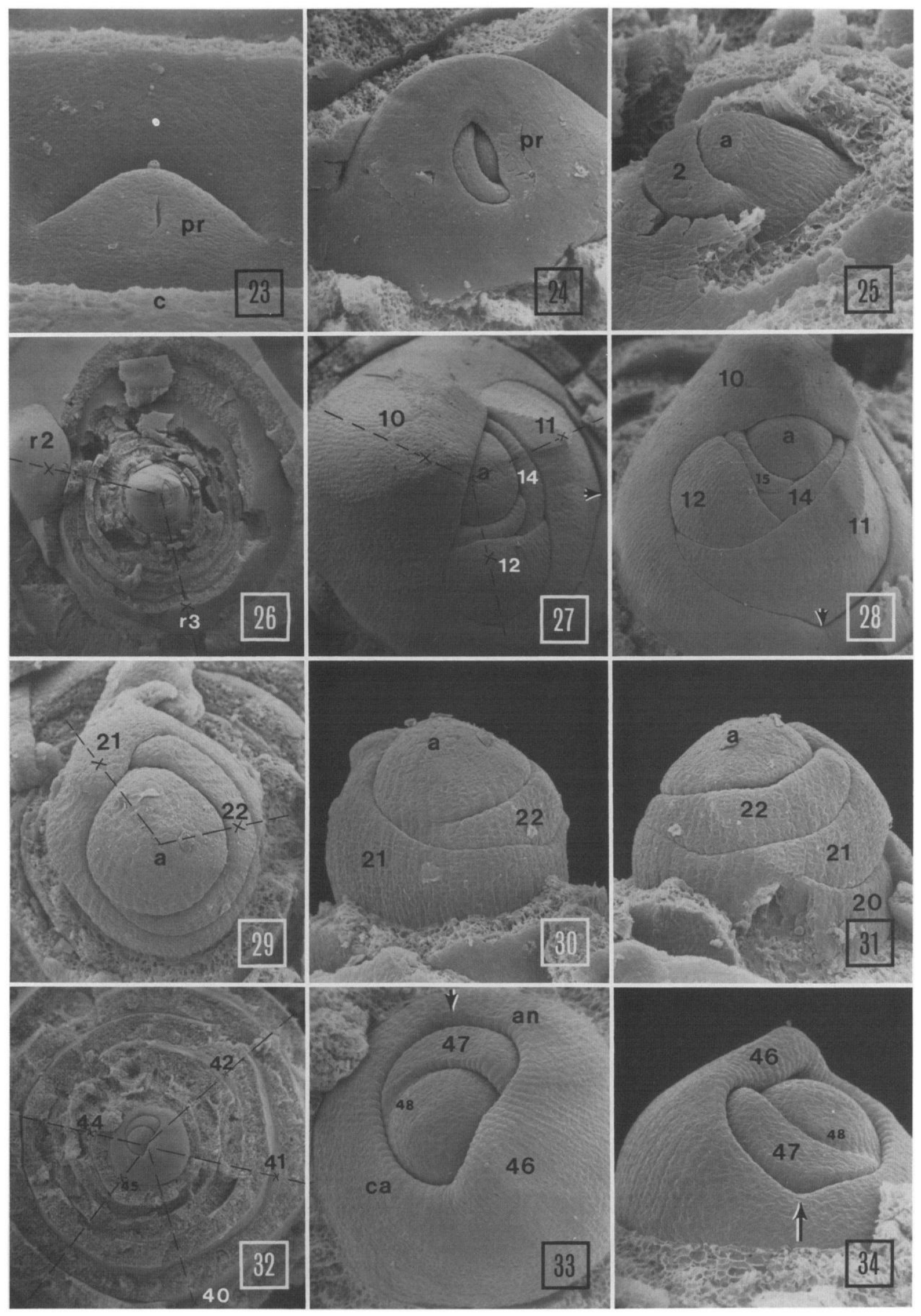



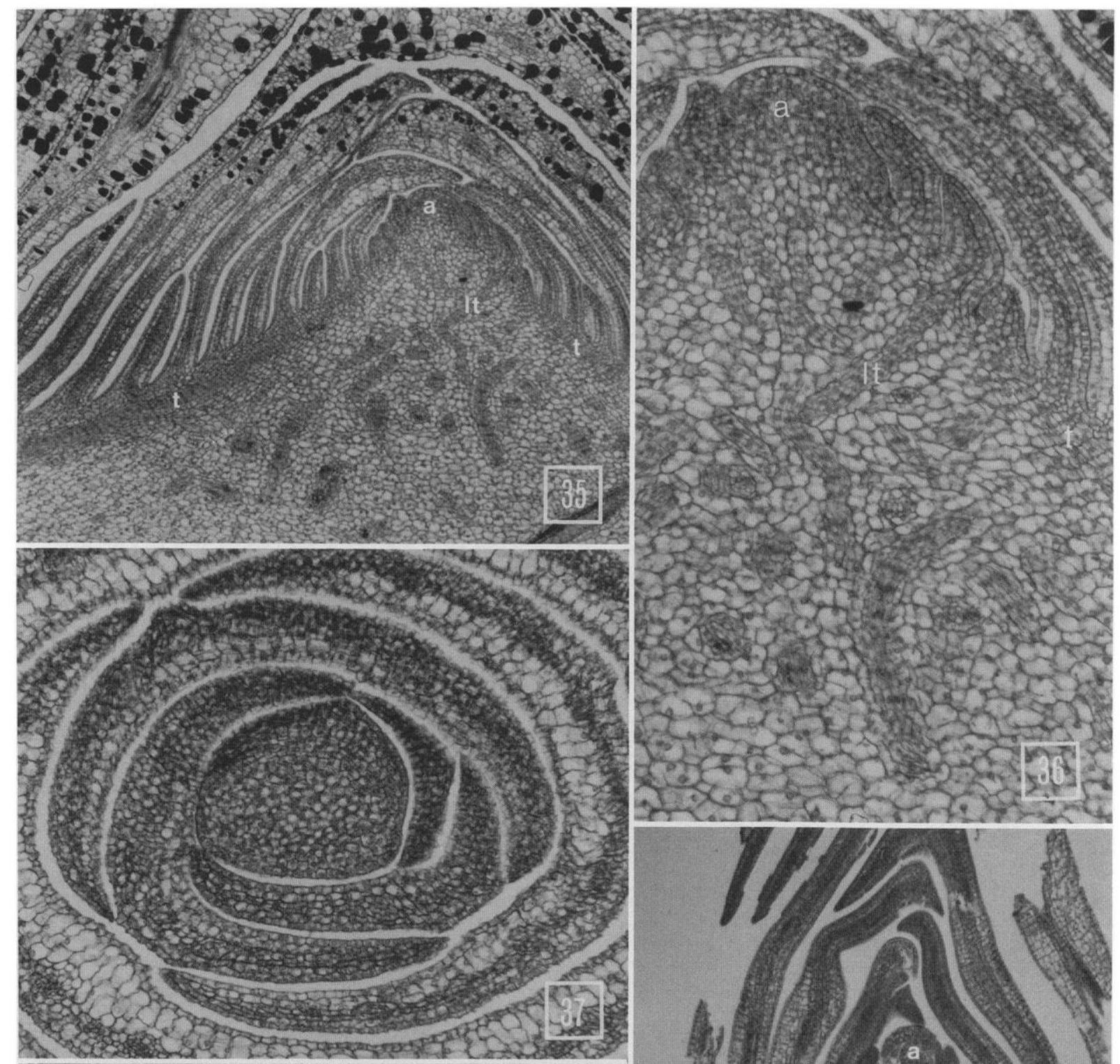

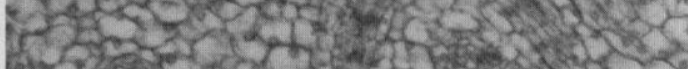

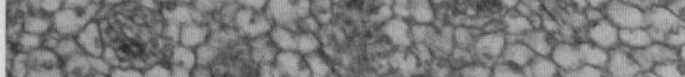

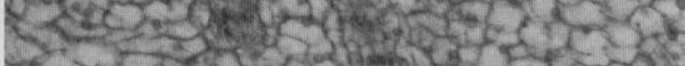
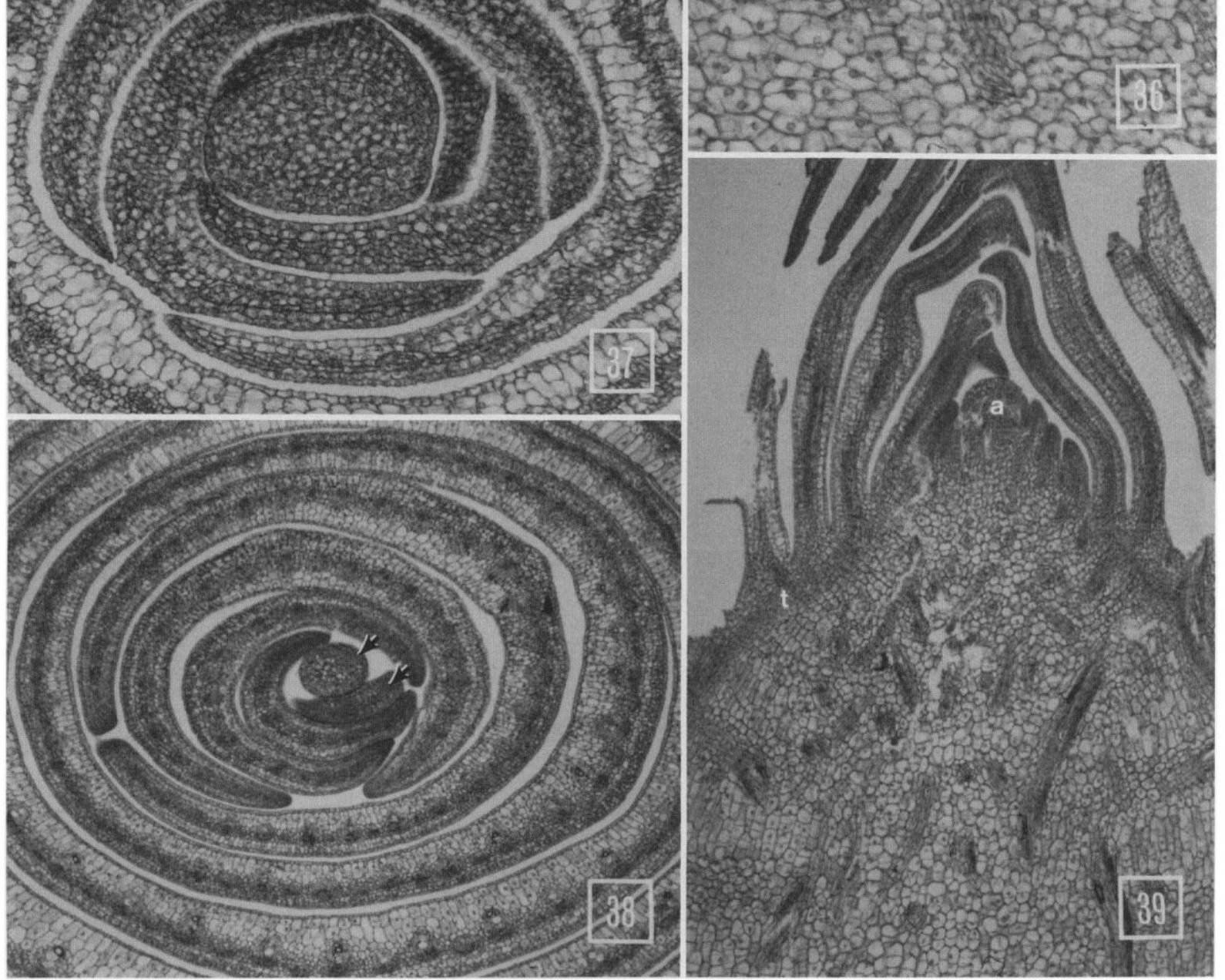

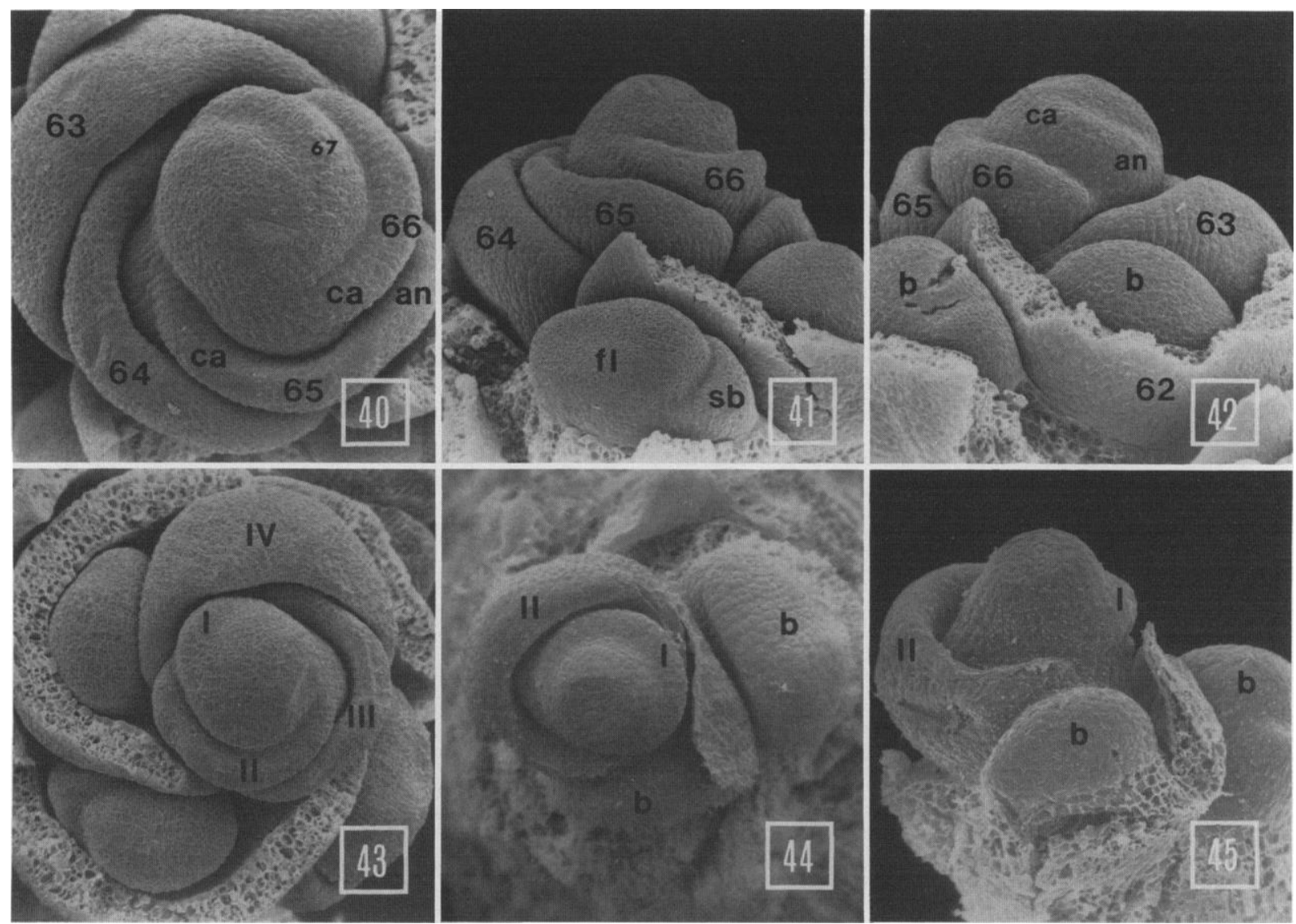

nos. 40-45.-Costus scaber. Scanning electron micrographs of inflorescence apices during initiation of bracts. Fig. 40, Polar view. The phyllotaxy is dextrose with a divergence angle of ca. $68^{\circ}$. The anodic margin (an) of each bract overlaps the cathodic margin $(c a)$ of the next younger bract. x 156. Fig. 41, Lateral view. Note the young flower $(f l)$ with its secondary bract $(s b)$ borne on the anodic side. x 130. Fig. 42, Lateral view. Note that the anodic margin (an) of a bract primordium is borne lower on the apex than is the cathodic margin $(c a) . b=$ cincinnus buds. x 150. Fig. 43, Polar view of an inflorescence apical region during formation of uppermost bracts. The phyllotaxy is sinistrorse, with divergence angles around $90^{\circ}$. /, $/ /$, etc. = bract primordia numbered from the apex. x 156. Figs. 44, 45, Two views of an older inflorescence apex close to the time of its abortion. Two bract primordia are clearly visible $(1$, as are cincinnus buds $(b)$ in the axils of the next two older bracts. Fig. 44, Polar view. The divergence angle is ca. $120^{\circ}$. x 135 . Fig. 45 , Lateral view. Note the precocious development of the bract primordia. x 156.

be up to $3 \mathrm{~m}$ tall. The rhizome is formed from the basal portions of the aerial shoots, which remain at, or slightly below, the soil surface (figs. 1, 6).

The first two internodes of each module are short and grow horizontally (fig. 6, internodes 1 and 2). After producing this region, the apex turns upward, giving the rest of the shoot a vertical orientation. The subsequent internodes form the base of the aerial shoot and are shorter and of greater girth than those forming the distal portion of the plant (fig. 6). The basal portion of the aerial shoots often become bulblike, with a diameter of up to $5.5 \mathrm{~cm}$. Distally, the diameter of the shoot gradually decreases to ca. $1.2 \mathrm{~cm}$ in the region below the inflorescence.

New segments of the rhizome develop from buds subtended by the second and third cataphylls borne on the previous module (figs. 6,26 ). The positions of these buds are unusual in two ways. First, they are inserted in the upper half of the next higher internode, not at the level of insertion of the subtending leaf (fig. 6). Second, they are inserted in

FIGS. 35-39.-Costus scaber. Fig. 35, Longitudinal section of a young shoot (renewal bud) showing the apex (a), and thickening of the stem due to the activity of a thickening meristem $(\mathrm{t})$. it $=$ leaf trace diverging from the center of the stem into a leaf. x 52. Fig. 36, Detail of fig. 35. Note that the apical $(a)$ and the thickening $(t)$ meristems are not histologically continuous and that the leaf traces (It) bend sharply before diverging into the leaves. $\mathrm{x} 130$. Fig. 37, Cross section of a renewal bud showing a decline in divergence angles from ca. $120^{\circ}$ (older cataphylls) to $60^{\circ}$ (two cataphylls adjacent to the apex). x 130. Fig. 38, Cross section of a mature aerial shoot with divergence angle of ca. $60^{\circ}$. The sheathing leaf bases can be clearly seen in the older leaves. Two meristematic primordia are viable at the apex (arrows). x 52. Fig. 39, Longitudinal section of a mature aerial shoot. A thickening meristem is evident at the periphery of the stem $(t) . \mathrm{a}=$ apex. $\mathrm{x} 52$. 

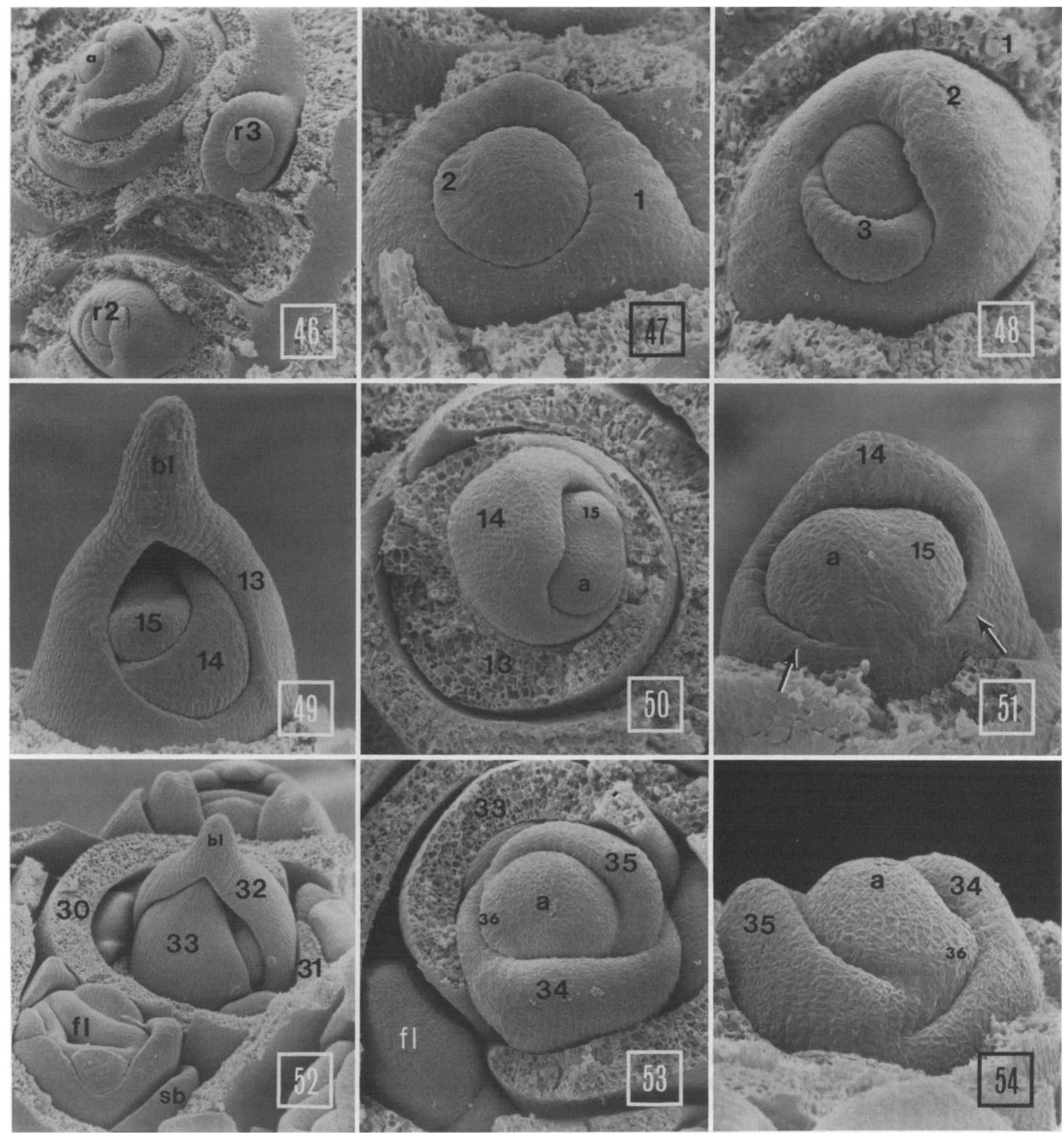

FIGS. 46-54. - Costus cuspidatus. Scanning electron micrographs. Figs. 46-48, Renewal buds. Fig. 46, Oblique view of dissected 6-mm-high renewal bud after the removal of six cataphylls. r2, r3, higher order renewal buds arising in near-axillary positions to cataphylls 2 and 3; a = main shoot apex. x 63. Fig. 47, Polar view of renewal bud $\mathrm{r} 3.1=$ prophyll; $2=$ second cataphyll. x 174. Fig. 48, Polar view of renewal bud r2. 1 = prophyll (removed); 2, 3 = cataphylls. x 180. Figs. 49-51, Early stages of foliage leaf development in apical region of a $4-\mathrm{cm}$-high shoot (module A in fig. 14). Fig. 49, Lateral view with 12 phyllomes removed. Note the tubular sheath and primordial blade (b1) on leaf 13. x 120. Fig. 50, Polar view after the removal of 13 phyllomes. The divergence angle is ca. $73^{\circ}$. a $=$ apex. x 140. Fig. 51, Lateral view of apical region shown in fig. 50. The youngest leaf primordium (leaf 15) is almost as large as the shoot apex (a). Leaf 14 has begun to develop its sheathing base (arrows). $x$ 235. Figs. 52-54, Apical region of an inflorescence terminating an aerial shoot. Fig. 52, Oblique view with 31 phyllomes removed. $\boldsymbol{b} \boldsymbol{l}=$ blade primordium; fl $=$ flower primordium; $\boldsymbol{s} \boldsymbol{b}=$ secondary bract on anodic side of flower. $\mathrm{x} 84$. Fig. 53, Polar view after the removal of 33 phyllomes. The phyllotaxy is dextrose with divergence angles approximating the main series Fibonacci angle of $137.5^{\circ}$. a $=$ apex; $\mathrm{fl}=$ flower primordium. $x$ 162. Fig. 54, Lateral view of infloresence apex shown in fig. 53. Note that the bracts lack tubular sheaths. a = apex. $x 240$. 
TABLE 1

Vegetative faAtures of Costus Cuspidatus, C. SCABER, AND C. WOOdSONII

\begin{tabular}{|c|c|c|}
\hline $\begin{array}{c}\text { C. cuspidatus } \\
\text { (subgenus Cadalvena) }\end{array}$ & $\begin{array}{c}\text { C. scaber } \\
\text { (subgenus Costus) }\end{array}$ & $\begin{array}{c}\text { C. woodsonii } \\
\text { (subgenus Costus) }\end{array}$ \\
\hline Height . . . . . . . . . . . . .5 m & $.5-3 \mathrm{~m}$ & $1-2 \mathrm{~m}$ \\
\hline Number foliage leaves .... . 6-15 & $18-42$ & $14-20$ \\
\hline Ligule . . . . . . . . . . 1-2 mm, glabrous & $2-12 \mathrm{~mm}$, hairy & $2-6 \mathrm{~mm}$, truncate \\
\hline Blade length $\ldots \ldots \ldots \ldots \ldots, 11-18 \mathrm{~cm}$ & $10-32 \mathrm{~cm}$ & $8-26 \mathrm{~cm}$ \\
\hline Blade width $\ldots \ldots \ldots \ldots \ldots .3 .5-6(-7.5) \mathrm{cm}$ & $3-11 \mathrm{~cm}$ & $4-11 \mathrm{~cm}$ \\
\hline Blade shape...$\ldots \ldots \ldots \ldots$ Narrowly elliptic to narrowly ovate & $\begin{array}{l}\text { Narrowly elliptic, cuneate to } \\
\text { rounded }\end{array}$ & $\begin{array}{l}\text { (Narrowly) ovate to } \\
\text { (narrowly) obovate }\end{array}$ \\
\hline Flowers per inflorescence ... . 3-8 & Numerous & Numerous \\
\hline Bracts ............. Herbaceous & Persistent & Persistent \\
\hline Appendages on bracts ...... Green, foliaceous & Absent & Absent \\
\hline
\end{tabular}

NOTE.-Data from MAAS 1972, 1977, supplemented by new observations.

one sector of the rhizome, facing the direction of growth (figs. 7,A, A'; 26). This arrangement orients the buds away from the older sections of the rhizome, thus providing adequate room for continued growth (fig. 7).

Under normal situations it is the bud subtended by the second cataphyll that produces the single renewal shoot (figs. 6A; 26). This renewal bud occurs on alternating sides of successive axes (figs. $1,7)$. In general, only one renewal axis is produced. However, it is occasionally possible to find two axes developing from the same parent shoot. In these cases, the renewal buds subtended by the second and third cataphyll produce new modules (fig. 7,A, $\mathrm{A}^{\prime}$ ). Of 128 rhizome segments growing in one clump at Fairchild Tropical Garden, only four produced two renewal shoots from the same parent axis. In all four cases the previous axis had aborted at an early stage of growth. However, there is no one-to-one correspondence between shoot abortion and the production of two renewal shoots. One rhizome was observed in which only one renewal shoot was produced following the abortion of the previous shoot. In this case, the renewal shoot produced a rhizome segment growing in a different direction from the old rhizome.

The phyllotactic helix reverses direction with each renewal shoot (fig. 7). Thus, the phyllotaxy of successive axes alternates between sinistrorse and dextrorse. This pattern places the renewal shoots on alternating sides of adjacent modules and produces the zigzag pattern characteristic of Costus (figs. 1, 7) (HALLE 1967).

Costus cuspidatus. - Costus cuspidatus is a smaller plant than $C$. scaber. Its aerial shoots are 50$65 \mathrm{~cm}$ in length. Consequently, the number of cataphylls and foliage leaves is considerably smaller than in C. scaber (table 1).

Each module adds two to three nodes/internodes to the sympodial rhizome before turning upward to produce an aerial shoot. Unlike $C$. scaber, the basal portions of the aerial shoots do not show a prominent swelling (fig. 14).

There are four enlarged buds on each rhizome module in C. cuspidatus, not two as in C. scaber. These buds are restricted to one sector of the rhizome, facing the direction of continued growth (fig. 15). Each bud is subtended by a cataphyll. Thus, the one-sided placement of the enlarged buds coincides with the arrangement of their subtending leaves. The buds are somewhat displaced to the internode above the subtending cataphyll, although less obviously so than in C. scaber.

A single renewal bud normally grows out to produce a new module (fig. 15A). As in C. scaber, the modules produced by successive renewal buds are arranged in a zigzag pattern and the direction of the phyllotactic helix of the foliage leaves and upper cataphylls is reversed in successive modules (figs. $7 ; 15$, bud A). The renewal bud in the axil of cataphyll 3 (fig. 15, A') also occasionally produces a renewal shoot. When this occurs a branched rhizome results.

\section{ARCHITECTURE OF THE AERIAL SHOOTS}

Costus scaber. - The aerial shoots are unbranched, and bear 11-24 cataphylls in their basal regions and 18-42 foliage leaves distally (fig. 2). The terminal inflorescence (fig. 10) bears between 50 and 82 bracts over a period of several months (KIRCHOFF 1988). At Fairchild Tropical Garden the flowering period usually extends from April through September. However, it is occasionally possible to find inflorescences and flowers as late as December.

Each foliage leaf consists of a tubular sheathing base surmounted by a ligule, a short petiole, and a lamina (fig. 9). There is a substantial amount of overlap between the sheaths of adjacent phyllomes (fig. 8), which significantly contributes to the strength of the stem.

The size of the blades, sheaths, and internodes in one aerial shoot varies considerably and in a more 
or less regular way along the shoot (fig. 20a). Sheath and internode lengths gradually increase from the rhizome to the insertion of the first foliage leaf (fig. 20a, solid arrow). From this point, sheath length decreases to the inflorescence. Internode length decreases from the first foliage leaf to the inflorescence where it remains small and relatively constant.

Blade length remains relatively constant throughout the foliage leaf region $(X=26.0 \mathrm{~cm}$, no. $=$ 23, S.D. = 1.26). The transition leaves on either side of this region have smaller blades, intergrading with the cataphylls on one side and the inflorescence bracts on the other (figs. 10-12, 20a). All of the phyllomes subtend buds, most of which do not develop into shoots. Several of the uppermost transition leaves and the lowermost one or two of the inflorescence bracts subtend axillary buds that develop into vegetative propagules after flowering.

The inflorescence consists of a single main axis that bears helically arranged bracts (fig. 10). Each bract subtends a cincinnus consisting of a single flower (KIRcH0FF 1988) (fig. 13). The secondary bract (the prophyll) borne on the cincinnus axis always occurs on the anodic side of the flower (figs. $13 ; 41, \mathrm{sb})$.

After flowering, the axillary buds at the base of the inflorescence grow out to form vegetative propagules (bulbils, MAAS 1972). The weight of these propagules causes, or contributes to, the inclination of the aerial shoot. Inclination occurs at one of the basal internodes of the shoot. As the weight of the propagules increases, the whole shoot gradually inclines, lowering the inflorescence and propagules to the ground. In this position, the propagules take root and produce a new rhizome system.

Costus woodsonii.-Leaf blade length is smaller in $C$. woodsonii than in $C$. scaber and there are fewer leaves with fully developed blades $(X=17.6$ $\mathrm{cm}$, no. $=10$, S.D. $=0.6)$. There is a gradual decrease in the blade length of the upper foliage leaves toward the infloresence, rather than an abrupt transition to the inflorescence bracts (fig. 21a). As a consequence, there are a greater number of transition leaves in this species. The ratio of the number of transition leaves to total foliage plus transition leaves is ca. 0.38 in $C$. woodsonii and ca. 0.26 in C. scaber.

As in C. scaber, sheath and internode lengths generally increase toward the first foliage leaf, remain more or less constant in the region of the lower foliage leaves, and decline toward the inflorescence (fig. 21a).

Costus cuspidatus. $-A s$ in C. scaber, the aerial shoots are unbranched. Seven to eight cataphylls are borne at the base of the shoot, followed by five to six foliage leaves, and a terminal inflorescence. The cataphylls and foliage leaves resemble those already described for $C$. scaber (figs. 16, 17); both have prominent tubular sheaths. Changes in sheath and blade length along a shoot of C. cuspidatus are shown in figure 22a. As in C. scaber, the upper foliage leaves produce vegetative propagules.

The inflorescence bracts of C. cuspidatus have an open sheath and are green and foliaceous (figs. $3,18,19)$. Thus, except for the open sheath, the bracts of $C$. cuspidatus are similar in structure to the transition leaves of $C$. scaber. Within the inflorescence, there is a gradual decrease in blade length (fig. 22a). Each bract subtends a one-flowered cincinnus with a secondary bract (the prophyll) on the anodic side of the flower (fig. 52).

\section{PHYLLOTAXY OFTHE AERIAL SHOOTS}

Costus scaber.-The phyllotactic pattern in the Costaceae is unique. The aerial shoots in this family are characterized by helical phyllotaxy with very low divergence angles, sometimes as low as $30^{\circ}$ (fig. 5). This type of phyllotaxy has been termed spiromonostichous, helicomonostichous, or simply costoid (SNOW 1952).

Divergence angles are not constant, but change in a gradual and regular way along a shoot (figs. 20b, 37). In C. scaber, the divergence angle gradually drops from ca. $130^{\circ}$ in the rhizome to ca. $90^{\circ}$ in the region of the lowermost foliage leaf (fig. 20b, solid arrow). In the middle of the foliage leaf zone the divergence angle drops to ca. $60^{\circ}$. From this point, it rises to $80^{\circ}-90^{\circ}$ in the region of the uppermost foliage leaves, just below the inflorescence (fig. 20b, open arrow). Within the inflorescence, the divergence angle falls again to ca. $55^{\circ}$, then may rise again, occasionally reaching $110^{\circ}$ (fig. 44).

Costus woodsonii. In $C$. woodsonii the diver-

gence angle falls from $130^{\circ}\left(-140^{\circ}\right)$ to $60^{\circ}-40^{\circ}$ in the middle of the foliage leaf region (fig. 21b). From this point, it increases to ca. $100^{\circ}$ in the region of the uppermost foliage leaves. A second decline in divergence angle begins with the first bract. Within the inflorescence, the divergence angle falls from ca. $100^{\circ}$ to $60^{\circ}\left(-70^{\circ}\right)$ in the middle of the inflorescence. With the last few bracts of the inflorescence the divergence angle may increase again to $70^{\circ}-90^{\circ}$ (fig. $21 \mathrm{~b}$ ).

Costus cuspidatus. - The divergence angles observed along the aerial shoots in C. cuspidatus (fig. $22 b)$ deviate considerably from those observed in C. scaber and C. woodsonii. Distal to the renewal buds (figs. 14, 15, 46), the two to three remaining cataphylls are arranged along a helix with divergence angles between $65^{\circ}$ and $100^{\circ}$. The divergence angles between these cataphylls never exceed $100^{\circ}$ as they do in C. scaber and C. woodsonii. The divergence angles drop only slightly, to $50^{\circ}$ $70^{\circ}$ between the cataphylls and the foliage leaves (fig. 22b).

The lowermost two or three inflorescence bracts 
have the same size and structure as foliage leaves, with a tubular sheath and a large blade (fig. 22a, blade length). In the inflorescence, the divergence angles remain low, with similar values to those found in the cataphyll and foliage leaf regions, i.e., $60^{\circ}-90^{\circ}$. Above the lowermost two or three bracts the divergence angles abruptly increase to around the Fibonacci angle $\left(137.5^{\circ}\right)$. All of the remaining bracts are inserted at approximately this angle (fig. 22b).

The switch from a spiromonostichous pattern in the cataphyll and foliage leaf regions to a Fibonacci pattern in the inflorescence is correlated with a switch from tubular to open sheaths on the bracts (cf. figs. 17, 18, 49 with 19, 54).

\section{DEVELOPMENTAL ASPECTS}

Costus scaber. - The prophyll is the first phyllome initiated on a renewal bud. It completely covers the shoot apex at an early stage of development, leaving only a small slit on the abaxial side of the apex (fig. 23). As more leaves form, the prophyll enlarges and opens to reveal the apex and young cataphylls (fig. 24). The divergence angle between the prophyll and the second cataphyll is ca. $90^{\circ}$ (figs. 24,25 ). We consider the flattened shape of this cataphyll (fig. 24, phyllome 2) and of the apex itself as an indication that they are under pressure from the prophyll. Although it has not been possible to determine the position of initiation of the third phyllome, the bud subtended by this phyllome lies ca. $120^{\circ}$ from the bud subtended by phyllome 2 (fig. 26). The possibility that these renewal buds do not lie in the axils of their respective leaves makes the determination of phyllome divergence angles difficult in this region.

The divergence angles higher in the cataphyll region of a young renewal bud are ca. $120^{\circ}$ (figs. $27,29)$, in agreement with those measured from mature shoots (fig. 20b, leaves 10-15). Soon after formation, the basal regions of the cataphyll primordia become strongly imbricate (fig. 28). In approximately its sixth plastochrone of growth the primordium has enlarged to cover the apex (figs. $27 ; 28$, leaf 10). At this stage, the primordium envelops half of the apex with a hoodlike covering and its well-developed sheath surrounds the bud. Further dissection of the apical bud shows that the leaf sheaths of the younger cataphylls do not completely encircle the apex at this stage (figs. 30, 37).

The position of a notch on the cathodic side of the sheath indicates that development of the sheath is not completely symmetric (figs. 27; 28 , arrow). The cathodic side is larger than the anodic. We take the flattened primordia to indicate that they have developed under pressure from the outer cataphylls (figs. 27-31).

During the production of foliage leaves, the subapical region is more steeply domed and the inter- node lengths immediately below the apex are shorter than during cataphyll formation (cf. figs. 27-31 with 32-34 and 35 with 39). During foliage leaf production, the leaf in the third plastochrone has already developed an encircling sheath and has begun to cover the apical dome (figs. 33 ; 34, primordium 46). The young foliage leaves do not appear to be as closely pressed to the apex as do the hooded cataphylls previously discussed (cf. figs. 33, 34 with 28-31). The encircling sheaths found in the foilage leaf region may be clearly seen in cross section (fig. 38 ).

Cross sections of an apex actively producing foliage leaves show that two meristematic primordia are borne on the apex at one time (fig. 38). The younger of these is represented by an arc of densely cytoplasmic cells attached to the side of the apex. The older primordium has both densely cytoplasmic and vacuolating cells.

Within one plastochrone of their formation, both the sheath and blade of a foliage leaf become asymmetric. The cathodic side of the sheath enlarges more than the anodic (figs. 33, 34). This asymmetric development is expressed as a notch in the anodic side of the sheath (figs. 33; 34, arrow). As growth continues, the position of this depression, coupled with the precocious development of the anodic side of the leaf, gives the young primordium a decidedly asymmetric appearance. By the time the mature leaf unrolls from the bud, the anodic margin has enclosed the cathodic.

During leaf formation, the apical dome inclines toward the cathodic margin of the leaf in the third plastochrone of growth (fig. 33, primordium 46). This orientation may be due to the initiation of a new leaf that causes the apex to grow toward the cathodic margin of the older leaf (fig. 33).

The inflorescence apex produces bracts in a sequence that continues the helix established in the vegetative region (figs. 40-43). Bracts are initiated relatively high on the apical dome with their cathodic margin overlapping the anodic margin of the previous bract (fig. 40 , bract $66 \mathrm{ca}$, bract 65 an). The anodic margin of a bract is inserted lower on the apex than is its cathodic margin (figs. 41; 42 , bracts 65-67). This oblique insertion gives rise to a sequence of closely imbricate bracts (fig. 10).

The inflorescence bracts enlarge and cover the apex at a later plastochrone than do the leaves. In the mid-inflorescence region, the eleventh bract has enlarged enough to partially cover the apex. Thus, a greater number of bracts cluster around the inflorescence apex than leaves or cataphylls cluster around the vegetative apex.

The divergence angle in the mid-inflorescence region is ca. $60^{\circ}-68^{\circ}$ (figs. $10,20 \mathrm{~b}, 40$ ) in the specimen investigated in this study. However, B. K. KIRCHOFF has observed angles as low as $45^{\circ}$ in $C$. scaber inflorescences. 
As the inflorescence terminates, differentiation of the axillary buds and enlargement of the bracts occur closer to the apex (figs. 43-45). The height of the free apical dome also increases. The result of these processes is that the number of bracts clustered at the apex decreases as the apex terminates (cf. figs. 40-42 with 43-45). Correlated with these changes is an increase in divergence angles. As the inflorescence apex ages, the divergence angles increase (fig. 20b). In the apex illustrated in this paper, the divergence angles increase from $68^{\circ}$ (fig. 40 ), to $90^{\circ}$ (fig. 43 ), to $120^{\circ}$ (fig. 44).

Each bract subtends an axillary bud that develops into a cincinnus. The cincinnus consists of a single terminal flower and a lateral secondary bract (prophyll). The secondary bract is always produced on the anodic side of the cincinnus (fig. $41, \mathrm{sb})$. Thus, within an inflorescence the cincinni are all of the same handedness.

Costus cuspidatus. - The first phyllome formed on a renewal bud is the adaxially inserted prophyll (fig. 47). In C. cuspidatus this prophyll does not close over the apex as quickly as it does in $C$. scaber. The second cataphyll is initiated ca. $90^{\circ}$ from the prophyll (fig. 47, phyllome 2) and begins to close over the apex by plastochrone 2 (fig. 48). The divergence angle between the second and third cataphylls is ca. $120^{\circ}$ (fig. 48).

The apical bud of $C$. cuspidatus shows similarities with that of $C$. scaber during foliage leaf formation (cf. figs. 32-34 with 49-51). As in C. scaber, contact between phyllome primordia and the region of the shoot apex is more pronounced during cataphyll than during foliage leaf production (cf. fig. 48 with 49-51). Similarly, enlargement of the leaf primordia is more rapid in the foliage leaf zone than in the cataphyll zone. In the foliage leaf zone, the second to third leaf primordium $\left(\mathrm{P}_{2}\right.$ to $\mathrm{P}_{3}$ ) has already ensheathed and overtopped the shoot apical area (fig. 49-51, leaves 13, 14).

Foliage leaf development begins with the formation of a primordium on one side of the shoot apex. This primordium becomes almost as large as the remaining apex before the next primordium is initiated (figs. 50; 51, leaf 15). By plastochrone 2, the apical portion of the leaf primordium has begun to develop into the leaf blade (figs. 50; 51, leaf 14). An ensheathing leaf base also develops at this stage (fig. 51, arrows). Both of these structures continue to enlarge, so that by plastochrone 3 they are well developed (fig. 49, leaf 13).

Although both the bracts and foliage leaves possess green blades (fig. 3), bract development differs from foliage leaf development in several respects. First, since the bracts are nonsheathing, the bract primordia do not develop sheathing bases (fig. $54)$. Second, the size of the youngest bract primordium $\left(P_{l}\right)$ is smaller, relative to the size of the apex, than is the corresponding foliage leaf (cf. figs.
50 , 51 with 53,54$)$. Third, the number of plastochrones for a phyllome to enclose the apex also differs between foliage leaves and bracts. The fifth to sixth bract primordium covers the apex (fig. 53, bracts 32,33 ).

One similarity between bract and foliage leaf development is correlated with the possession of a blade, or blade rudiment, in both of these classes of phyllomes. By the fourth to fifth plastochrone, an elongated tip can be clearly distinguished on the bract primordium (fig. 52,bl). A similar structure develops by the third plastochrone on the foliage leaf primordia (fig. 49, leaf 13,b1). In both cases, this tip will develop into the blade or its precursory tip.

\section{ANATOMY AND VASCULATURE OF THE APICAL REGION IN COSTUS SCABER}

This section briefly surveys the developmental anatomy of Costus scaber. A detailed study of the developmental anatomy in the Costaceae is beyond the scope of this article.

Two meristematic regions may be distinguished at the tip of the shoot in C. scaber: an apical meristem and a lateral thickening meristem. While neither region was investigated in detail, a number of general observations were made.

The apical meristem is organized into a tunica and corpus. The tunica consists of a single cell layer covering a corpus (fig. 36). The thickening meristem is an area of meristematically active cells located just interior to the insertion of the leaves (figs. $35, \mathrm{t} ; 36, \mathrm{t} ; 39, \mathrm{t})$. There does not appear to be a meristematic connection between the thickening meristem and the apex proper.

The apical region is more broadly conical in a shoot actively producing cataphylls (i.e., a renewal bud, fig. 35) than in an aerial shoot producing foliage leaves (fig. 39). This difference is most likely due to the activity of the thickening meristem in the younger shoot (fig. 35,t). Cell divisions in this region cause the stem to widen relatively close to the apex.

The course of the leaf traces entering the stem is similar to the situation in Alpinia speciosa (a synonym of A. zerumbet) described by BELL (1980) (see figs. 35,1t; 36,1t).

\section{Discussion}

The main problem confronting the study of phyllotaxy in Costus is devising an adequate hypothesis to explain the unusual leaf arrangement in this genus. Here we review some previous theories in the light of our observations. This analysis provides the background necessary for the formulation of adequate theories in the future. Discussion of some of the older papers on costoid phyllotaxy is found in SCHüEPP (1928), WEISSE (1932), TROLL (1937), and SMITH (1941). 
Most phyllotactic theories are based on observations of leaf arrangement at the shoot apex (first available space theory, morphogen theory, RUTISHAUSER 1981; RUTISHAUSER and SATTLER 1985; LACROIX and SATTLER 1988). One of the most frequently made observations is that new leaves are initiated in regions of the apex as far as possible from all other leaves (HOFMEISTER 1868). This phenomenon, called Hofmeister's rule, is one of the limiting criteria for the establishment of Fibonacci and related phyllotactic patterns (RICHARDs 1951). This rule has been violated in some phyllotactic systems: Bromea edulis (Amaryllidaceae) Lachenalia spp. and Paris sp. (Liliaceae) (TROLL 1937, p. 428; MULLER- DOBLIES et al. 1987). However, it is rare for leaves and buds to be inserted at divergence angles lower than $100^{\circ}$, as in Costus. For these low divergence angles to occur, each successive leaf must be initiated in the vicinity of the next older leaf. Thus, instead of being initiated as far as possible from the older leaves, a new primordium forms close to one of these leaves. The first available space theory of SNOW and SNOW (1947) and several of the morphogen theories are clearly violated by these patterns.

Other phyllotactic theories might be more successful in explaining costoid phyllotaxis or even superposition of organs. PLANTEFOL 's theory of foliar helices postulates that a new leaf is induced by signals from the next older leaf along the same foliar helix (PLANTEFOL 1946-1947, LOISEAU 1969). In spite of the speculative nature of these acropetally moving signals, this theory could explain the occurrence of divergence angles between $0^{\circ}$ and $100^{\circ}$. GREEN'S biophysical model of hoop reinforcement also might explain costoid phyllotaxis and organ superposition (GREEN 1988, LACROIX and SATTLER 1988). JEAN'S (1988) conceptual model, though involving a phylogenetic perspective, claims to explain various extraordinary phyllotactic patterns, including costoid phyllotaxis.

The phyllotaxy of Costus shows many unusual features. The first several cataphylls are borne on one sector of the rhizome at divergence angles between $100^{\circ}$ and $130^{\circ}$ (SCHUEPP 1928). This arrangement is clearly functional in orienting the renewal buds in a sector of the shoot away from the older portions of the rhizome. However, it is difficult to explain in terms of phyllotactic theory without hypothesizing some inhibitory influence from the parent module. Similar patterns of phyllome arrangement are found in some inflorescences of the Marantaceae (Zingiberales) whose bracts are arranged on one side of the axis: Thalia (KIRCHOFF 1986) and Ctenanthe (SCHUMANN 1902).

The phyllotactic patterns found above the first few cataphylls in Costus fall into two distinct classes. Costus scaber and C. woodsonii have relatively large divergence angles $\left(130^{\circ}-140^{\circ}\right)$ along the rhizome, approximating the ideal main series Fibonacci angle of $137.5^{\circ}$. In these species, the divergence angles fall to ca. $60^{\circ}$ in the middle of the foliage leaf region. From this point they rise to ca. $90^{\circ}-100^{\circ}$ at the base of the inflorescence, where they remain below $100^{\circ}$. In $C$. cuspidatus the divergence angles in the cataphyll and foliage leaf regions of the shoot remain below $100^{\circ}$. Only at the transition to the inflorescence do the divergence angles increase significantly. After a short transition zone, the divergence angles stabilize around the main series Fibonacci angle of $137.5^{\circ}$ in the inflorescence.

Correlated with these changes in divergence angle are changes in the forms of the phyllomes. In all three species the cataphylls consist solely of a tubular sheath while the foliage leaves possess a closed sheath, a short petiole, a blade, and a ligule. In $C$. scaber and $C$. woodsonii the possession of a blade is restricted to the foliage leaves, while in C. cuspidatus both the foliage leaves and bracts have blades. All except the lowermost inflorescence bracts have open sheaths in all three species (fig. 12).

SCHUMANN (1892) explains costoid phyllotaxis by the asymmetry of the young leaf sheath: new leaf primordia appear on the apex in a position exactly above the notch in the closed, asymmetric leaf sheath of the next older primordium. That new leaves do not appear in this position has been demonstrated in our study (fig. 33, arrow = notch in sheath, 48 = new leaf). HIRMER (1922) and SCHüEPP (1928) also criticize SCHUMANN'S (1892) hypothesis. They point out that if new leaves arose in the notch of the next older leaf sheath, the divergence angle would be ca. $150^{\circ}-180^{\circ}$, not $60^{\circ}-90^{\circ}$.

SCHUMANN (1899) also claims that costoid phyllotaxy occurs only where the leaf bases are completely sheathing. He bases this conclusion on a study of $C$. tappenbeckianus and C. lucanusianus. SNOW (1952) supports this claim with examples of inflorescences where the bracts have open sheaths and show noncostoid, often Fibonacci, phyllotaxy. An example of a species with these characteristics is C. cuspidatus.

Although SCHUMANN'S claim offers an easy explanation for the presence of costoid phyllotaxy, additional study shows that it is incorrect. Costus scaber and $C$. woodsonii have both nonsheathing bracts and costoid phyllotaxy. The literature provides at least one additional example to invalidate SCHUMANN'S claim. VON VEH (1931, p. 108) publishes photographs of an inflorescence of C. spicatus that has bracts with open sheaths and costoid phyllotaxy. Based on our observations of other species of Costus, the association of nonsheathing bracts with costoid phyllotaxy seems to be a common situation. Cases where sheathing bracts are arranged in a noncostoid pattern are more rare.

In the Zingiberaceae, SPEARING (1977) finds 
closed leaf sheaths in Cautleya gracilis, Roscoea cautleoides, $R$. humeana, $R$. procera, $R$. purpurea, and $R$. alpinia. All of these species have distichous phyllotaxy, as is common in the Zingiberaceae. SPEARING also draws attention to the fact that microtome sections of the leaf bases of Hedychium spp. indicate closed sheaths in this genus. The species cited as evidence of this fact were studied by BOYD (H. gardnerianum) (1932) and WEISSE $(H$. coccineum and $H$. coronarium) (1932). The sheaths are closed only at the very base in these species.

In addition to foliage leaves, SPEARING (1977) investigates closed leaf sheaths in the inflorescences of $R$. cautleoides and $R$. humeana and finds at least some closed sheaths in both of these species, although their position in the inflorescence was varible. Both of these species have distichously arranged bracts. Based on these observations, he concludes that the relationship suggested by SCHUMANN (1899) is not obligatory.

GOEBEL (1924, 1928), VON VeH (1931), and TROLL (1937) propose that costoid phyllotaxy is derived from distichy by a congenital torsion of the shoot apex. This torsion causes the leaves to be inserted at the small divergence angles characteristic of costoid phyllotaxy rather than at $180^{\circ}$, as is characteristic of distichy. According to TROLL (1937, p. 430), the torsion is due to an asymmetric growth of the shoot apex that is due to the flow of nutrients along a helical path in the apex. The amount of torsion needed per plastochrone is $130^{\circ}$ in those shoots where the divergence angles are $50^{\circ}$ $\left(180^{\circ}-130^{\circ}=50^{\circ}\right)($ TROLL 1937 , fig. 336). We find no evidence of torsion in our study of Costus.

SCHUEPP (1928) stresses the difficulties in explaining costoid phyllotaxy as the result of observable spatial patterns or by gradients of physiologically active substances. He attributes costoid phyllotaxis to the properties of the shoot apex itself but states that these properties are not directly observable.

WEISSE (1932) suggests that the tubular leaf bases exert pressure against the shoot apex. According to WEISSE, the midribs of the older leaves not directly in contact with the apex can exert indirect pressure through the younger leaves on the same radius. Since pressure has been shown to retard leaf formation (NEMEC 1903), WEISSE proposes that the new primordium will appear not in the region farthest from the other primordia, but in the region where the pressure against the apex is least. WEISSE (1932, p. 347) attributes the high degree of "fluctuation" of divergence angles along a shoot to the weak (indirect) influence of pressure in determining the site of leaf initiation.

SNOW (1952) is in general agreement with WEISSE (1932), but thinks that his theory could only account for the continuation of the phyllotactic sys tem, not its establishment in the seedling. SNOw bases this conclusion on his judgment that the pressure from at least five sheathing leaves is needed to maintain a costoid placement of primordia. SNOW'S solution to this problem is based on his discovery that the shoot apex is tilted away from the last formed primordia $(P$,$) , and rests against$ P3. According to SNOW, the tilt of the apex means that it only requires the pressure from three leaves to maintain the costoid pattern. This makes it possible for costoid phyllotaxy to be established in the seedling, as observed by WEISSE (1932) in a number of species.

SNOW'S (1952) observations on the tilt of the apex have been confirmed for foliage leaves in our study. However, at least in the case of renewal shoots, the apex is not inclined during cataphyll formation. Since the first phyllomes formed upon germination are cataphylls, it is unlikely that SNOW'S solution provides a satisfactory explanation for the establishment of costoid phyllotaxy in the seedling.

A slightly different explanation for costoid phyllotaxy is offered by SMITH (1941), following general indications given by HOFMEISTER (1868). She attributes the small divergence angles in Costus to the fact that there is never more than one meristematic primordium at the apex at one time. This situation arises because, according to SMITH, Costus has a very long plastochrone. Thus, the new primordium does not compete with any older primordia for space and can arise "in that part of the apex most favorable for its growth, irrespective of the position of the one immediately preceding it." SMITH'S observations have not been confirmed in this study, at least as regards the mature aerial shoot of $C$. scaber where two meristematic primordia can be seen at the apex (fig. 38, arrows).

The results obtained in the present study raise serious questions about all of the theories discussed above. Neither torsion of the shoot apex (GOEBEL 1924, VON VEH 1931, TROLL 1937), nor SCHUEPP'S (1928) properties of the apex have been observed. The theories of both WEISSE (1932) and SNOW (1952) require that pressure by the leaf sheaths is exerted on the shoot apex to produce costoid phyllotaxy. Our study of bract arrangement around the inflorescence apex in C. scaber shows that a costoid pattern occurs in this species without any contact between the developing bracts and the apex. KIRCHOFF's (1988, fig. 5) illustrations of the inflorescence apex of the same species show that even the older bracts do not contact the apex. SNOw (1952) refers to a similar situation in C. spicatus, illustrated by VON VEH (1931). Since this was the only example known to him, and only from an illustration, he called for further investigation of the pattern and did not reject WEISSE'S (1932) and his own theories. With the addition of our informa- 
tion, it can be concluded that pressure is not the most important factor determining costoid phyllotaxy, at least in the inflorescence.

A second observation that is not adequately addressed by the existing theories is the change in divergence angles along a shoot. If leaf placement were determined only by the pressure of leaf sheaths on the apex or by the fact that there is only one meristematic primordium at the apex, the divergence angles should not change in the regular way found in Costus. The observed change in divergence angles means that some other factor(s) influence leaf arrangement.

SMITH (1941) describes a change in divergence angles along a shoot but refers to the change as variability: "The angular divergences between successive leaves are extremely variable; the divergences between scale leaves (from $1 / 2$ to $1 / 4$ of the circumference) are always greater than between foliage leaves (from $1 / 5$ to $1 / 7$ of the circumference)." She explains this "variability" by postulating that the vascular system, and in particular the median leaf trace, determines the position of the primordia. In this, she follows PRIESTLEY et al. (1935) whose ideas have recently been revived by LARSON (1975).

In addition to observing precocious development of procambial strands, SMITH (1941) reports that the median leaf trace diverges tangentially from its longitudinal course one node below the insertion of the leaf that it vascularizes. For example, according to SMITH, the median trace of leaf 15 follows a course that takes it ca. $30^{\circ}$ in the cathodic direction as it passes between nodes 14 and 15 . According to SMITH, curvature of this sort is a common, but not a constant, feature of the course of the median leaf trace. She attributes the change in the course of this strand to the asymmetrical growth of the side of the "apical cone," at the level of insertion of the margins of the next older primordium, i.e., primordium 14 in this example. In this region, she reports a meristematic zone uniting the marginal meristem of the leaf with the "greater depth of meristem on the flank of the apical cone." According to her, the radial and tangential growth of this united meristem leads to the deflection of the procambial strand "away from the marginal meristematic region at this node."

The importance of the deviation of the median strand is that it accounts for the "variability" in divergence angles. Since SMITH (1941) does not report that divergence angles change in a regular way along a shoot, she explains the "variability" by changes in the degree of deflection of the median leaf traces. Her argument is not convincing due to the fact that she only presents data on the deflection of one median trace and the position of its corresponding leaf. Even if more data were available, it is difficult to understand how the activity of the united meristem could produce the divergence of the median trace that she claims it does. It is also difficult to explain the regular change in divergence angles along a shoot according to this theory.

In order further to test SMITH'S (1941) hypothesis, we followed the course of several median traces through three to four internodes before their insertion into leaves. We have been unable to verify SMITH'S report of the deviation in the course of the median trace as it approaches a leaf. Based on these observations and on the theoretical difficulties discussed above, we reject SMITH'S hypothesis as an adequate explanation for the change in divergence angles along a shoot in Costus.

Apart from the Costaceae, most of the other families of the Zingiberales have a distichous leaf arrangement. The Musaceae, with spirally arranged leaves, are an exception to this rule. According to SKUTCH (1927), the divergence angles in Musa sapientum change along the shoot in a manner similar to that found in Costus. In young suckers the divergence angle determined from the overlapping leaf sheaths is ca. $2 / 5\left(144^{\circ}\right)$. If the divergence angle of these same shoots is determined from the arrangement of the blades, it is closer to $1 / 3\left(120^{\circ}\right)$. SKUTCH attributes this discrepancy to a "slight torsion of the pseudostem." Older "ratoons" show a clear 2/5 phyllotaxy in both the blades and sheaths. As the pseudostem enlarges, the phyllotaxy changes to $3 / 7\left(154^{\circ}\right)$ and finally to $4 / 9\left(160^{\circ}\right)$ in the mature flowering plant. Thus, in at least this species of Musa, the divergence angles continually increase as the plant matures. However, the divergence angle never falls below $120^{\circ}$ as it does in Costus. This type of progressive change is a common situation in plants that show a change in phyllotaxy along the stem (HACCIUS 1939, 1950; RUTISHAUSER 1981). It is in marked contrast to the situation in Costus where the phyllotaxy first decreases, then increases, toward the inflorescence.

The distichous phyllotaxy in both the ginger group and the banana group suggests that the common ancestor of the ginger group also possessed this type of phyllotaxy. This conclusion is based on outgroup comparison (STEVENS 1980) between the ginger and banana groups and the assumption that the spiromonostichy of the Costaceae is not homologous to the spiral phyllotaxy of the Musaceae. If we accept this argument, then the Costaceae must have evolved from an ancestor with distichous phyllotaxy.

This evolutionary hypothesis should be clearly distinguished from HIRMER's (1922) typological theory on the origin of costoid phyllotaxy. HIRMER suggests that costoid phyllotaxy arose from a distichous system through the total loss (sensu TUCKER 1984) of one parastichy of leaves. We have two 
objections to this theory. First, total loss is not directly observable. Thus, confirmation for this theory can only come from the discovery of an intermediate species with a suppressed (sensu TUCKER 1984) parastichy. Since to our knowledge no such species exists, HIRMER's theory can never be supported. Rather, this theory is part of what may be termed "idealistic phyllotactic theory." Second, even if a distichous plant lost one parastichy, it is unclear why the remaining leaves would be arranged in a costoid pattern. Why would a Fibonacci pattern not result? Considered by itself, the loss of one parastichy is not enough to explain the origin of costoid phyllotaxy.

Helical phyllotactic patterns with divergence angles below $100^{\circ}$ are found in various taxa outside the Zingiberales, e.g., several conifers, Crassulaceae, Euphorbia spp., and Lycopodium spp. However, in these cases the leaves always have small, nonsheathing leaves with an insertion angle of less than $60^{\circ}$ of the circumference (CHURCH 1920, RUTISHAUSER 1982, ZAGORSKA-MAREK 1985), i.e., the leaf primordia are small in relation to the size of the apex. Cases of organ superposition, though rare in the vegetative region (Utricularia spp.) (RUTISHAUSER and SATTLER, in press), are found regularly in many flowers (JEAN 1988, LACROIX and SATTLER 1988).

Unlike the leaves, the inflorescence bracts are spirally arranged in a number of families of the Zingiberales. In the banana group, the Musaceae are the only family with spiral bracts. In the ginger group, all of the families have at least one representative with spirally arranged bracts. Spirally arranged bracts are very common in the Zingiberaceae, occurring in many of the genera. In the Marantaceae, spirally arranged bracts occur in most species of Calathea. The remaining members of this and other genera in the family have either distichous bracts or two-ranked bracts that converge to one side of the inflorescence (Thalia) (KiRCHOFF 1986). In the Cannaceae, spirally arranged bracts are present in all species of the single genus Canna. Although there has been little detailed study of spiral bract arrangement in any of these families, the bracts generally appear to be arranged in main series Fibonacci spirals. The one exception to this is the Cannaceae where the bracts are three-ranked, with divergence angles of ca. $120^{\circ}$.

Several lines of research need to be pursued to more accurately determine what factors influence the formation of costoid phyllotaxy. First, more exact study of the relationship between the apex and the young phyllomes is needed to determine if pressure plays any role in determining costoid phyllotaxy. Our data indicate that pressure is not the primary factor determining costoid phyllotaxy. However, it may have a minor role in determining the site of leaf initiation in the cataphyll or foliage leaf region. Information is needed for both the cataphyll and foliage leaf regions of several species. Three-dimensional reconstructions of apices preserved in a noncoagulant, nonshrinking fixative would be an ideal way to provide the required information. If it is confirmed that the apex is under pressure, an additional test for the influence of pressure would be to see if removing pressure from the apex by microsurgery influences where the next leaf is formed.

Second, plastochrone ratios (RICHARDS 1951; RUTISHAUSER 1981) are needed for a number of stages of shoot development, i.e., a number of phyllotactic patterns along a shoot. These measurements are needed for both vegetative and inflorescence apices for those species that (1) show costoid phyllotaxy throughout and (2) change phyllotactic patterns between the vegetative shoot and inflorescence. This information will determine if there is a specific relationship between the size of the apex and the size of the leaf primordia that is necessary for the formation of costoid phyllotaxy.

Third, measurements of the absolute size of the shoot apex at various developmental stages, i.e., during scale leaf, foliage leaf, and bract formation would be helpful. This information will determine if absolute size of the apex plays any role in determining costoid phyllotaxy.

Fourth, new data are needed on the developmental anatomy of the shoot apex. It is particularly important to study the relationship between the procambial strands and the apex. Such a study provides the information to evaluate SMITH' s hypothesis that the position of the leaves is determined by the vasculature in Costus.

After more than $120 \mathrm{yr}$ of study, the puzzle of costoid phyllotaxy still remains. None of the currently existing theories explains all of the phenomena associated with this unusual phyllotactic pattern. Although SCHUMANN (1899), WEISSE (1932), SMITH (1941), and SNOW (1952) contribute important observations, their theories are unable to account for at least one of the observations described in this article. Data on various aspects of apex size and architecture may provide a clue to the solution of this fascinating puzzle.

\section{Acknowledgments}

Portions of this research were carried out while B. K. KIRCHOFF was a research associate and R. RUTISHAUSER was a guest at Fairchild Tropical Garden. We thank Fairchild Tropical Garden for making their facilities available to us during this study. We are grateful to Dr. ROLF SATTLER and to two anonymous referees for their valuable comments on the manuscript. The technical assistance of Mr. U. JAUCH (SEM), Mr. A. ZUPPIGER (photography), and Ms. B. HASLER (illustration of figs. 
6-19) is also gratefully acknowledged. This research material is based on work supported by the National Science Foundation under grants BSR-
8307103 and BSR-8800178 and by University of North Carolina at Greensboro Research Council grant 555418 to B. K. KIRCHOFF.

\section{LITERATURE CITED}

BELL, A. 1980. The vascular pattern of a rhizomatous ginger (Alpinia speciosa L. Zingiberaceae). I. The aerial axis and its development. Ann. Bot. 46:203-221.

BERLYN, G. P., and J. P. MIKSCHE. 1976. Botanical microtechnique and cytochemistry. Iowa State University Press, Ames.

BOYD, L. 1932. Research on the embryo and seedling of monocotyledons. Trans. Bot. Soc. Edinb. 31:1-224.

CHURCH, A. H. 1920. On the interpretation of phenomena of phyllotaxis. Hafner, New York.

CROIZAT, L. 1960. Principia botanica. Vol. 1A. Self-published, Caracas.

GOEBEL, K. 1924. Die Entfaltungsbewegungen der Pflanzen und deren teleologische Deutung. G. Fischer, Jena.

1928. Organographie der Pflanzen. 3d ed. Vol. 1. G. Fischer, Jena.

GREEN, P. B. 1988. A theory for inflorescence development and flower formation based on morphological and biophysical analysis in Echeveria. Planta 175:153-169.

HACCIUS, B. 1939. Untersuchungen über die Bedeutung der Distichie für das Verständnis der zerstreuten Blattstellung bei den Dikotylen. Bot. Arch. 40:58-150.

1950. Weitere Untersuchungen zum Verständnis der zerstreuten Blattstellung bei den Dikotylen. Sitzungsber. Heidelberger Akad. Wiss. Math.-Naturwiss. Klin. 6:289337.

HALLE, N. 1967. Aframomum polyanthum (K. Schum.) K. Schum. et Costus dinklagei K. Schum. Adansonia, Ser. 2, 7:73-80.

1979. Architecture du rhizome chez quelques Zingibéracées d'Afrique et d'Océanie. Adansonia, Ser. 2, 19:127144.

HIRMER, M. 1922. Zur Lösung des Problems der Blattstellungen. G. Fisher, Jena.

HOFMEISTER, W. 1868. Allgemeine Morphologie der Gewächse. Engelmann, Leipzig.

JEAN, R. V. 1984. Mathematical approach to pattern and form in plant growth. Wiley, New York.

1988. Phyllotactic pattern generation: A conceptual model. Ann. Bot. 61:293-303.

KIRCHOFF, B. K. 1986. Inflorescence structure and development in the Zingiberales: Thalia geniculata (Marantaceae). Can. J, Bot. 64:859-864.

1988. Inflorescence structure and development in Costus scaber (Costaceae). Can. J. Bot. 66:339-345.

Lacroix, C., and R. SAtTler. 1988. Phyllotaxis theories and tepal-stamen superposition in Basella rubra. Am. J. Bot. 75:906-917.

LARSON, P. R. 1975. Development and organization of the primary vascular system in Populus deltoides according to phyllotaxy. Am. J. Bot. 62:1084-1099.

LINDMAN, C. A. M. 1899. Zur Morphologie und Biologie einiger Blätter und belaubter Sprosse. Bihang till Sven. Vet.-Akad. Handl. Vol. 25, afd. 3, no. 4.

LOISEAU, J.-E. 1969. La phyllotaxie. Masson, Paris.

MAAS, P. J. M. 1972. Costoideae (Zingiberaceae). Flora Neotropica Monograph 8. Hafner, New York.

1977. Renealmia (Zingiberaceae-Zingiberoideae),

Costoideae (additions). Flora Neotropica Monograph 18. Hafner, New York.

MULLER-DOBLIES, U., B. NORDENSTAM, and D. MULLER-DOBLIES. 1987. A second species in Lachenalia subgen. Brachyscypha (Hyacinthaceae): Lachenalia barkeriana sp. nov. from southern Little Namaqualand. S. Afr. J. Bot. 53:481-488.
NEMEC, B. 1903. Ueber den Einfluss der mechanischen Factoren auf die Blattstellung. Bull. Int. Acad. Sci. Boheme. 7:64-79.

Plantefol, L. 1946-47. Fondements d'une theorie phyllotaxique nouvelle: la théorie des helices foliaires multiples. Ann. Sci. Nat. Bot., Sér. 11, 7:153-229, 8:1-71.

PRiestley, J. H., L. I. Scam and E. C. Gilbert. 1935. The development of the shoot in Alstroemeria and the unit of shoot growth in monocotyledons. Ann. Bot. 49:161-179.

RICHARDS, F. J. 1951. Phyllotaxis: its quantitative expression and relation to growth in the apex. Philos. Trans. Roy. Soc., Lond., Ser. B, 235:509-564.

RUTISHAUSER, R. 1981. Blattstellung und Sprossentwicklung bei Blütenpflanzen unter besonderer Berücksichtigung der Nelkengewäche (Caryophyllaceen s.1.). Dissertationes Botanicae 62:1-166. J. Cramer, Verduz.

1982. Der Plastochronquotient als Teil einer quantitativen Blattstellungsanalyse bei Samenpflanzen. Beitr. Biol. Pflanzen 57:323-357.

RUTISHAUSER, R., and R. SATTLER. 1985. Complementarity and heuristic value of contrasting models in structural botany. I. General considerations. Bot. Jahrb. Syst. 107:415-455.

In press. Complementarity and heuristic value of contrasting models in structural botany. III. Case study on shootlike "leaves" and leaf-like "shoots" in Utricularia macrorhiza and $U$. purpurea (Lentibulariaceae). Bot. Jahrb. Syst. 111.

SCHUEPP, 0. 1928. Untersuchungen und Konstruktionen zur Theorie der einfachen Spiralstellung. Jahrb. Wiss. Bot. 5:867 886.

SCHUMANN, K. 1892. Morphologische Studien. Engelmann, Leipzig.

1899. Monographie der Zingiberaceae von Malaisen und Papuasien. Engler's Bot. Jahrb. 27:259-350.

1902. Marantaceae. Das Pflanzenreich no. 48, 4:1-176.

1904. Zingiberaceae. Das Pflanzenreich no. 4, 4:1-458.

SKUTCH, A. F. 1927. Anatomy of leaf of banana, Musa sap-

ientum L. Hort. Gros Michel. BOT. GAZ. 84:337-391.

SMITH, B. W. 1941. The phyllotaxis of Costus from the standpoint of development. Proc. Leeds Philos. Lit. Soc. (Sci. Sec.) 4:42-63.

SNOW, M., and R. SNOw. 1947. On the determination of leaves. New Phytol. 46:5-19.

SNOw, R. 1952. On the shoot apex and phyllotaxis of Costus. New Phytol. 51:359-363.

SPEARING, J. K. 1977. A note on closed leaf-sheaths in Zingiberaceae-Zingiberoideae. Notes Roy. Bot. Gard. Edinb. 35:217-226

STEVENS, P. F. 1980. Evolutionary polarity of character states. Ann. Rev. Ecol. Syst. 11:333-358.

TROLL, W. 1937. Vergleichende Morphologie der höheren Pflanzen. Vol. 1/1. Bontraeger, Berlin.

TUCKER, S. C. 1984. Origin of symmetry in flowers. Pages 351-395 in R. A. WHITE and W. C. DICKISON, eds. Contemporary problems in plant anatomy. Academic Press, Orlando, Fla.

Vox VeH, R. 1931. Untersuchungen und Betrachtungen zum Blattstellungsproblem. Flora. 125:83-154.

wEISSE, A. 1932. Zur Kenntnis der Blattstellungsverhältnisse bei den Zingiberaceen. Ber. Deutsch. Bot. Ges. 50:327-366.

ZAGORSKA-MAREK, B. 1985. Phyllotactic patterns, transitions, and the direction of the ontogenetic helix in Abies balsamea. Can. J. Bot. 63:1844-1854. 
http://www.jstor.org

\section{LINKED CITATIONS}

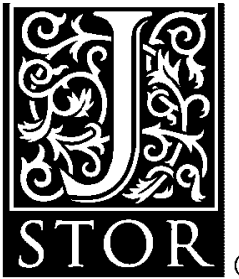

You have printed the following article:

\section{The Phyllotaxy of Costus (Costaceae)}

Bruce K. Kirchoff; Rolf Rutishauser

Botanical Gazette, Vol. 151, No. 1. (Mar., 1990), pp. 88-105.

Stable URL:http://links.jstor.org/sici?sici=0006-

8071\%28199003\%29151\%3A1\%3C88\%3ATPOC\%28\%3E2.0.CO\%3B2-G

This article references the following linked citations. Ifyou are trying to access articles from anoffcampus location, you may be required to first logon via your library web site to access JSTOR. Pleasevisit your library's website or contact a librarian to learn about options for remote access to JSTOR.

\section{Literature Cited}

\section{Phyllotaxis Theories and Tepal-Stamen Superposition in Basella rubra}

Christian Lacroix; Rolf Sattler

American Journal ofBotany, Vol. 75, No. 6. (Jun., 1988), pp. 906-917.

Stable URL:http://links.jstor.org/sici?sici=0002-

9122\%28198806\%2975\%3A6\%3C906\%3APTATSI\%3E2.0.CO\%3B2-F

Development and Organization of the Primary Vascular System in Populus deltoides According to Phyllotaxy

Philip R. Larson

American Journal ofBotany, Vol. 62, No. 10. (Nov. - Dec., 1975), pp. 1084-1099.

Stable URL:http://links.jstor.org/sici?sici=0002-

9122\%28197511\%2F12\%2962\%3A10\%3C1084\%3ADAOOTP\%3E2.0.CO\%3B2-Y

\section{Anatomy of Leaf of Banana, Musa sapientum L. var. Hort. Gros Michel}

Alexander F. Skutch

Botanical Gazette, Vol. 84, No. 4. (Dec., 1927), pp. 337-391.

Stable URL:http://links.jstor.org/sici?sici=0006-

8071\%28192712\%2984\%3A4\%3C337\%3AAOLOBM\%3E2.0.CO\%3B2-B

\section{On the Determination of Leaves}

Mary Snow; R. Snow

New Phytologist, Vol. 46, No. 1. (Jun., 1947), pp. 5-19.

Stable URL:http://links.jstor.org/sici?sici=0028- 


\section{LINKED CITATIONS \\ - Page 2 of 2 -}

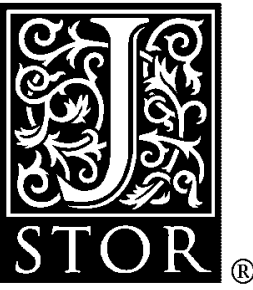

\section{On the Shoot Apex and Phyllotaxis of Costus}

R. Snow

New Phytologist, Vol. 51, No. 3. (Nov., 1952), pp. 359-363.

Stable URL:http://links.jstor.org/sici?sici=0028-

646X\%28195211\%2951\%3A3\%3C359\%3AOTSAAP\%3E2.0.CO\%3B2-V

\section{Evolutionary Polarity of Character States}

P. F. Stevens

Annual Review ofEcology and Systematics, Vol. 11. (1980), pp. 333-358.

Stable URL:http://links.jstor.org/sici?sici=0066-

4162\%281980\%2911\%3C333\%3AEPOCS\%3E2.0.CO\%3B2-I 